Syntax Literate : Jurnal Ilmiah Indonesia p-ISSN: 2541-0849 e-ISSN : 2548-1398

Vol. 5 No. 3 Maret 2020

\title{
APLIKASI SISTEM MANAJEMEN BELAJAR BERBASIS WEB DENGAN FRAMEWORK LARAVEL DI GROWTH2TECH
}

\author{
Ponsen Sindu Prawito dan Hardiansyah Putera Perdana \\ Politeknik Praktisi Bandung \\ Email:ponsen@praktisi.ac.id dan hardiansyahputraperdana03@gmail.com
}

\begin{abstract}
:
Learning Management System Application is a software application system based on information and communication technology. This system tool is useful for planning, implementing, and evaluating student learning processes and products. More than it, this system is useful to improve the quality improvement system of learning on an ongoing basis on this system based on WEB because have various advantages that make companies switch and are interested in using this application. In addition, currently there are quite a lot of people who access the internet through their mobile phones and tablets. Some of these advantages are easy to are develop and access, Easy server setup, information is easy to distribute and flexible in the making of this systeam he author uses the Laravel framework because Laravel is a contemporary web application framework, open source is used widely for designing fast and easy web applications and frameworks that use the php language which is still updating this system will be used by growth2tech companies that is an IT consulting company that helps in making web-based applications, mobile and graphic design.
\end{abstract}

Keywords: Learning management system application; WEB,Laravel; Growth2Tech

\begin{abstract}
Abstrak
Aplikasi Sistem Manajemen Belajar yaitu sistem aplikasi perangkat lunak berbasis teknologi informasi dan komunikasi. Perangkat sistem ini berguna untuk merencanakan, melaksanakan, dan menilai proses dan produk belajar siswa. Lebih dari itu, sistem ini berguna untuk meningkatkan sistem perbaikan mutu pembelajaran secara berkelanjutan pada sistem ini Berbasis WEB dikarenakan memiliki berbagai keunggulan yang membuat perusahaan beralih dan tertarik menggunakan aplikasi ini. Selain itu, saat ini cukup banyak masyarakat yang mengakses internet melalui telepon seluler dan tablet mereka beberapa keunggulan tersebut yaitu mudah untuk dikembangkan, mudah untuk diakses, setup server mudah, informasi mudah distribusikan dan fleksibel dalam pembutan sistem ini penulis menggunakan framework Laravel dikarenakan Laravel adalah framework aplikasi web kontemporer, open source digunakan secara luas untuk perancangan aplikasi web yang cepat dan mudah dan frameworks yang menggunakan Bahasa php yang masih update sistem ini akan dipakai pada perusahaan growth2tech yaitu perusahaan IT konsultan yang membantu dalam pembuatan aplikasi berbasis website, mobile serta desain grafis.
\end{abstract}


Kata kunci: Aplikasi sistem manajemen belajar; WEB,Laravel; Growth2Tech

\section{Pendahuluan}

Motivasi belajar merupakan unsur penting dalam belajar (Kholik, 2017). Pada era modern seperti sekarang ini, teknologi informasi dikembangkan sesuai dengan kebutuhan manusia agar dapat membantu serta memudahkan manusia dalam melakukan aktifitasnya. Salah satunya dengan banyaknya teknologi yang digunakan dalam memperoleh suatu informasi. Teknologi informasi sekarang ini dibutuhkan dalam berbagai bidang, baik itu bidang kesehatan, bisnis, pendidikan dan entertainment.

Pengaruh teknologi informasi dan komunikasi dalam dunia Pendidikan semakin terasa sejalan dengan adanya pergeseran pola pelatihan dari tatap muka yang konvensional ke arah pendidikan yang lebih terbuka dan bermedia dengan masuknya pengaruh globalisasi, pendidikan masa mendatang akan lebih bersifat terbuka dan dua arah, beragam, multidisipliner, serta terkait pada produktifitas kerja dan kompetitif.

Seiring perkembangan teknologi internet, e-learning mulai dikembangkan. Hakekat e-learning dalam bentuk pelatihan konvensional yang dituangkan dalam format digital melalui teknologi internet. E-learning dapat digunakan dalam pendidikan jarak jauh atau pendidikan konvensional tergantung dari kepentingannya. Mengembangkan model e-learning tidak sekedar menyajikan materi pelajaran ke dalam internet tetapi perlu dipertimbangkan secara logis dan memegang prinsip pelatihan. Begitu pula desain pengembangan yang sederhana, personal, cepat, serta terdapat evaluasi online.Evaluasi atau ujian online tidak lagi menggunakan kertas dalam menjawab cukup menclick aplikasi pada jawaban.Ujian online dapat lebih jelas menampilkan soal bergambar. Ujian online lebih cepat dalam menghitung hasil ujian sehungga guru dapat dengan mudah untuk membuat laporan nilai.

Tanpa menggunakan ujian online maka dalam pembuatan materi guru mengalami kesulitan dalam mengatur latihan soal. Penggunaan sistem manajemen belajar berbasis WEB agar memudahkan siswa dalam penggunaan sistem tanpa menginstall apapun dan siswa hanya berkunjung pada halaman website perusahaan untuk mendapatkan pelatihan.

Dari sekian keuntungan diatas maka dari itu penulis tertarik untuk merancang suatu sistem yang berbasis WEB sehingga sistem tersebut dapat diakses oleh siswa menggunakan berbagai versi browser. Penulis mengambil judul "Aplikasi Sistem Manajemen Belajar Berbasis WEB Dengan Framework Laravel, Di Growth2Tech". Maka dapat dirumuskan permasalahan (1) Bagaimana merancang dan membuat sistem manajement belajar berbasis WEB dengan menggunakan Laravel di growth2tech?. (2) Bagaimana mengimplementasikan dalam sistem manajement belajar berbasis web dengan menggunakan Laravel di growth2tech? 


\section{Metode Penelitian}

Dalam penelitian ini menggunakan metode pengembangan sistem Model Waterfall dan Teknik pengumpulan data Sumber data yang didapat dari Growth2Tech. Wicaksono (2017:165) mendefinisikan model waterfall lengkap beserta fase - fasenya sebagai berikut

"Waterfall adalah model klasik yang bersifat sistematis, berurutan dalam membangun software"

Fase -fase dalam model waterfall:

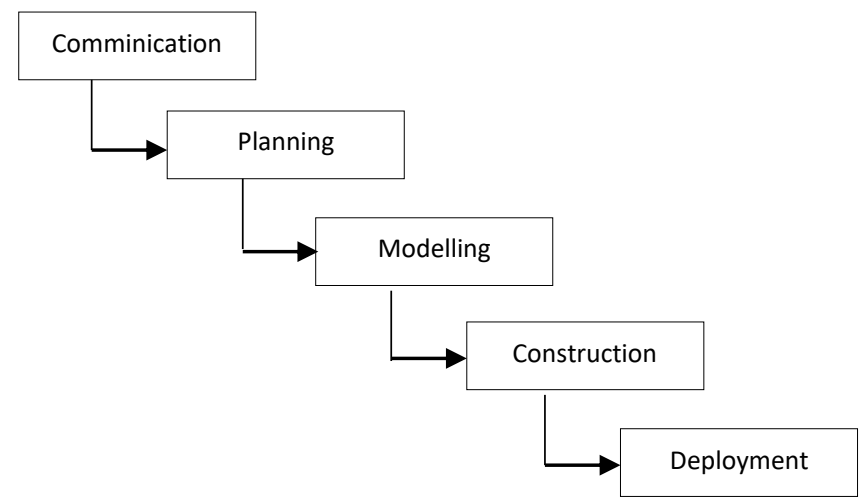

\section{Communication}

Gambar 1 Metonologi Waterfall

Langkah ini merupakan analisis terhadap kebutuhan software, dan tahap untuk mengadakan pengumpulan data dengan melakukan pertemuan dengan kostumer, maupun mengumpulan data - data tambahan baik yang ada di jurnal, article maupun internet.

\section{Planning}

Proses planning merupakan lanjutan dari proses Communication (analisis Requirement ). Tahapan ini menghasilkan dokumen user requirement atau bisa dikatakan sebagai data yang berhubungan dengan keinginan user dalam pembuatan software, termasuk rencana yang akan dilakukan.

\section{Modeling}

Proses modeling ini akan menerjemahkan syarat kebutuhan ke sebuah perancanga software yang dapat diperkirakan sebelum dibuat codingan. Proses ini berfokus kepada rancangan strultur data, arsitektur software, representasi interface, dan detail (algoritma) procedural. Tahapan ini akan menghasilkan document yang disebut software requirement.

\section{Construction}

Merupakan proses kode. Coding atau pengkodean merupakan penerjemahan desain dalam Bahasa yang dikenali oleh computer.Programmer akan menerjemahkan transaksi yang diminta oleh user. Tahapan inilah yang merupakan tahapan secara nyata dalam mengerjakan suatu software, artinya penggunaan computer akan dimaksimalkan dalam tahapan ini. Setelah 
pengkodean selesai maka akan dilakukan testing terhadap system yang telah dibuat dibuat tadi. Tujuan testing adalah menemukan kesalahan - kesalahan terhadap system tersebut kemudian untuk diperbaiki

\section{Deployment}

Tahapan ini bisa dikatakan final dalam pembuatan sebuah software atau system. Setelah melkukan analysis, desain desain dan pengkodean maka system yang sudah digunakan user. Kemudian software yang telah dibuat harus dilakukan pemiharaan secara berkala

\section{Hasil dan Pembahasan}

\section{Implemintasi Sistem}

a. Rancangan Fungsional (Functional Design)

Rancangan Funsional ini yaitu suatu gambaran dari informasidari informasi yang terjadi pada sistem yang bersangkutan. Perancangan yang dilakukan yaitu Aplikasi Manajement Belajar Berbasis web menggunakan framework Laravel di Growth2tech. Dengan adanya aplikasi ini diharapkan Growth2Tech dapat melakukan pembelajaran lebih maksimal lagi dibandingkan dengan menggunakan metode manual. Adapun perancangan aplikasi ini meliputi Use Case Diagram, Activity Diagram, ClassDiagram.

\section{1) Use Case Diagram}

Identifikasi Use Case Diagram :

Adapun perancangan Use Case Diagram dari aplikasi siste manajement belajar sebagai berikut :

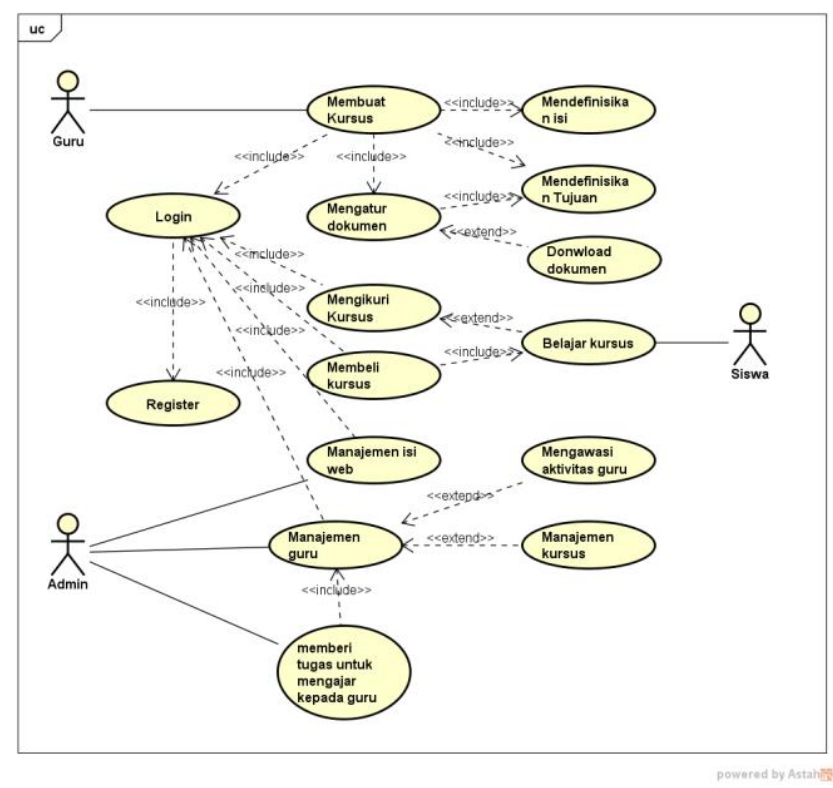

Gambar 2 Use Case Diagram

Seluruh pengolaan dilakukan oleh admin, Guru hanya mendapakan hak akses untuk add dan update course dan test, Guru tidak bisa menghapus kursus 
(course) dan test. Siswa dapat melihat course dan membeli course namun untuk membeli dan mengikuti test siswa harus login terlebih dahulu

2) Class Diagram

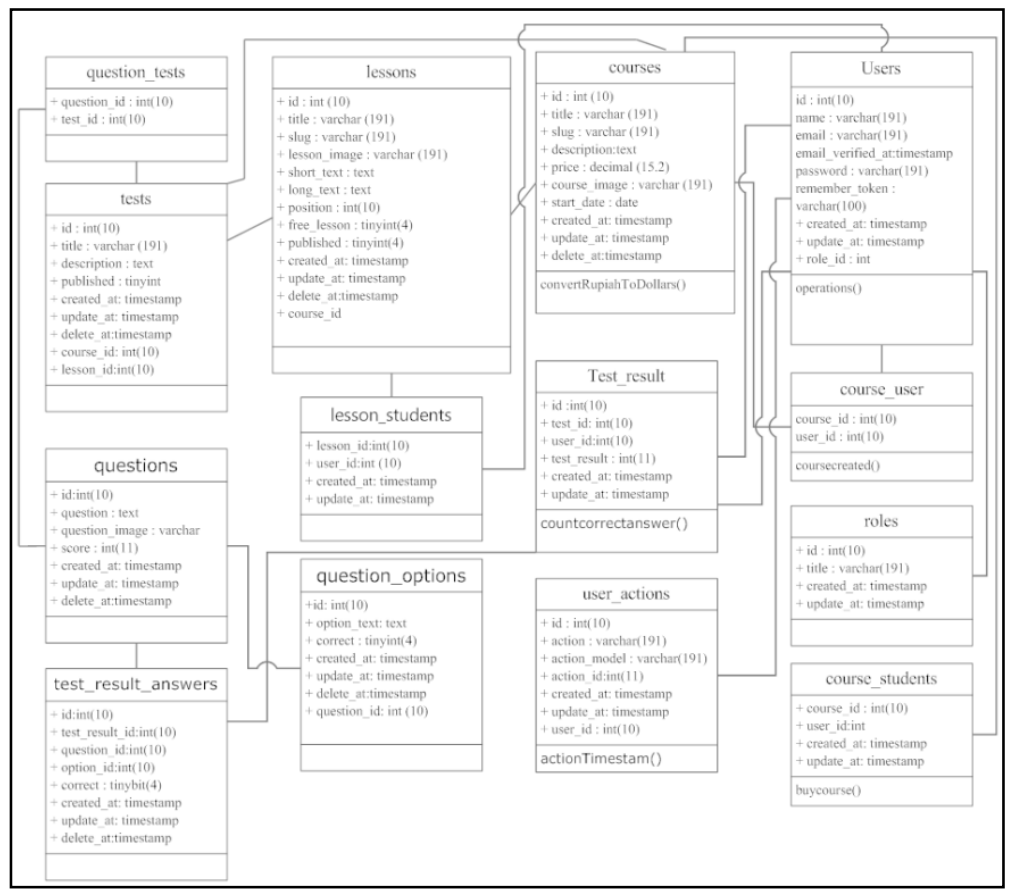

Gambar 3 Class Diagram

Class Users berhubungan dengan class lesson_students, test_result,user_actions, roles, dan courses. Dimana satu user bisa memiliki beberapa lesson_students, test_result, user_actions, roles, dan courses.Class Courses berhubungan dengan lesson, test, course_user dan course_student. Dimana satu Courses bisa memiliki beberapa lesson, test, course_user dan course_student.class lesson berhubungan dengan tests.Dimana satu lesson memiliki satu test. Class tests berhubungan dengan questions_tests. Dimana satu tests memiliki beberapa questions_tests

3) Activity Diagram

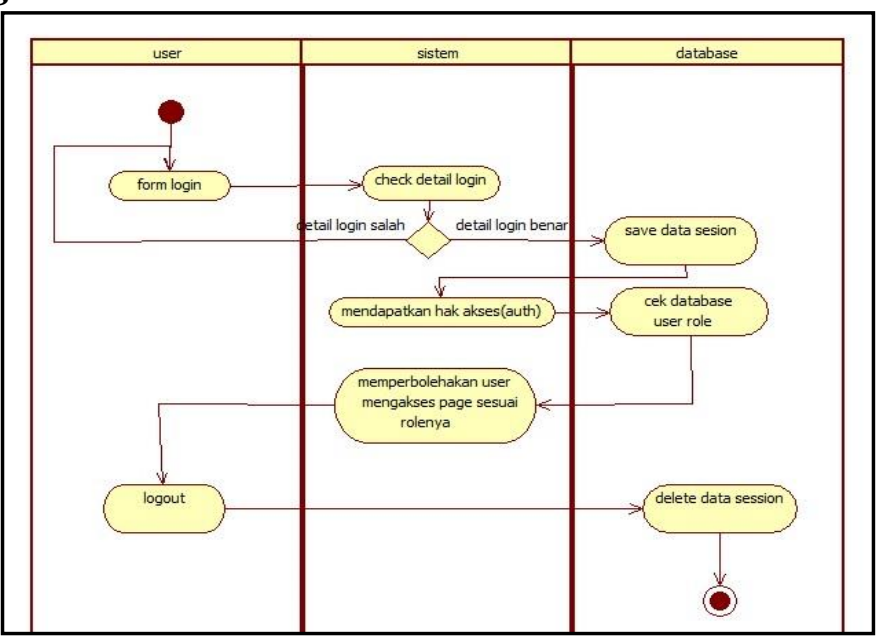

Gambar 4 Activity Diagram Login 
Activity Diagram diatas merupakan Activity diagram untuk melakukan login users setelah user login system akan menvertivikasi apakah role dari user tersebut apakah admin, guru (teacher), siswa(student) setelah diketahui role dari user maka system akan redirect sesuai dengan user role

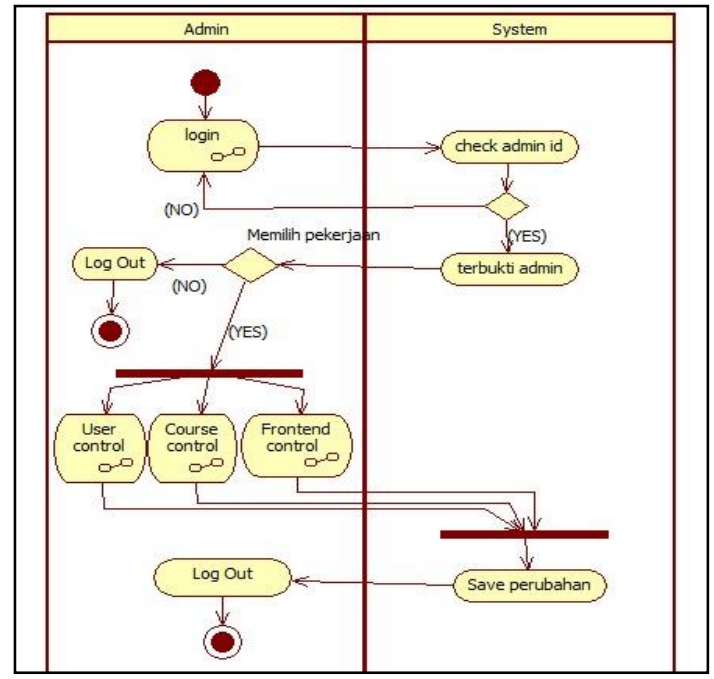

Gambar 5 Activity Diagram Admin

Activity diagram diatas menerangkan proses yang dilakukan oleh admin setelah login dan terbukti admin maka admin dapat melakukan control di admin panel maupun add, update maupun delete yang ada di admin panel yaitu users control, course control, dan frontend control.

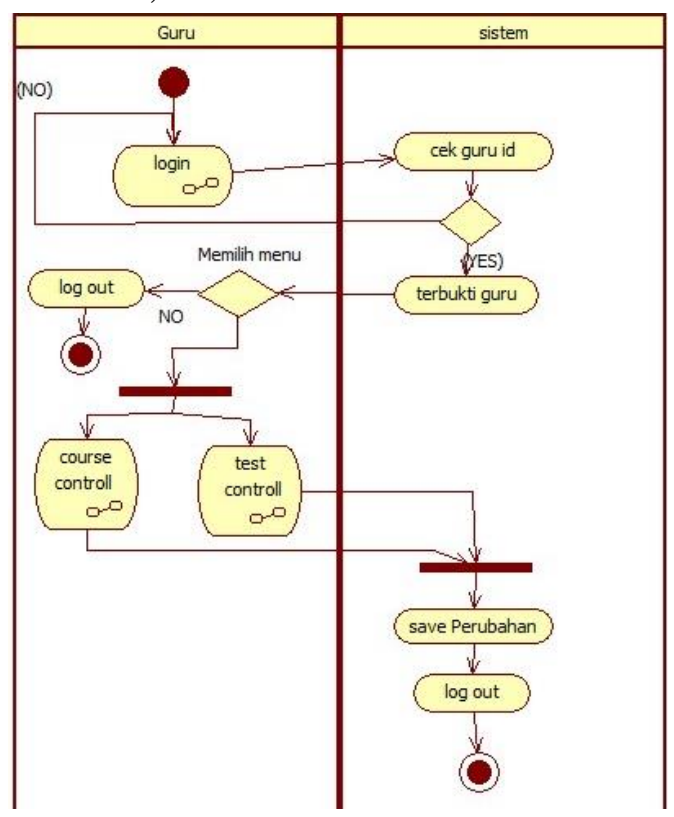

Gambar 6 Activity Diagram Guru (teacher)

Activity diagram diatas menerangkan proses yang dilakukan oleh guru setelah login dan terbukti guru maka gur dapat melakukan control di admin panel, guru hanya bisa melakukan add dan update. di admin panel guru hanya memiliki hak akses pada menu course control dan test control. 


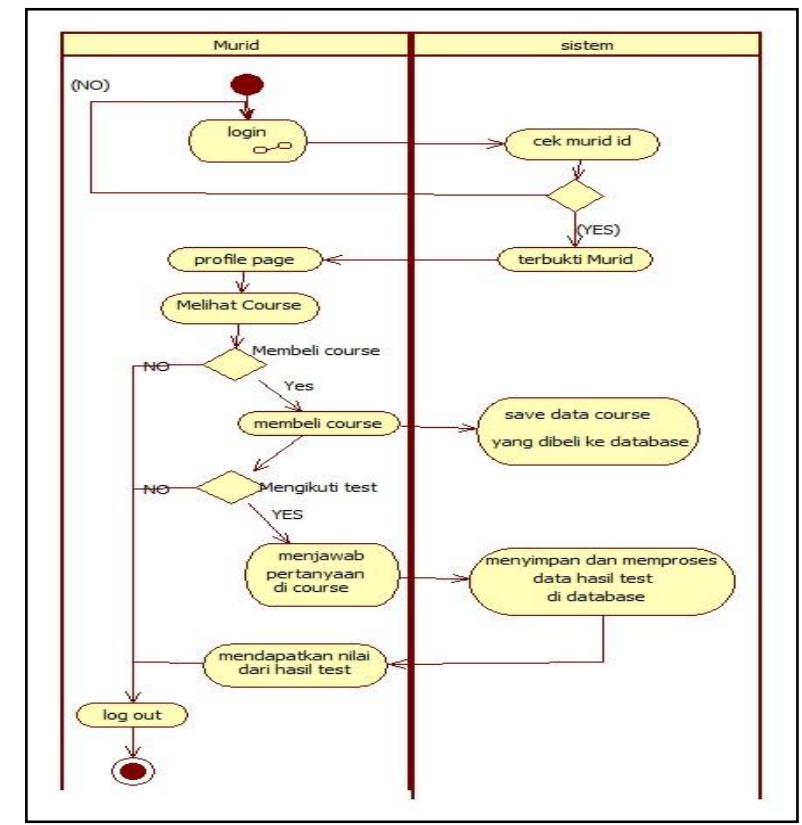

Gambar 7 Activity Diagram siswa (student)

Activity diagram menjelaskan proses siswa dalam system setelah melakukan login siswa akan dapat mengakses profile page dan dapat membeli course semua course yang sudah terbeli akan terdapat pada profile page dan siswa dapat mengikuti test dari kursus (course) yang dibeli.

4) Sequence Diagram

Gambaran sequence diagram pada Aplikasi.

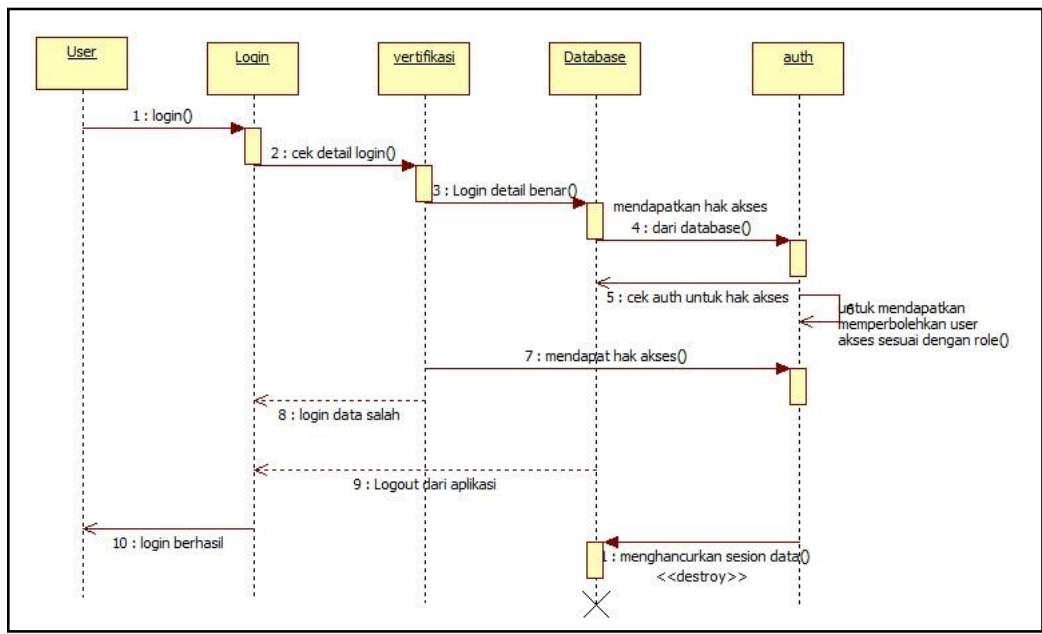

Gambar 8 Sequence Diagram login 


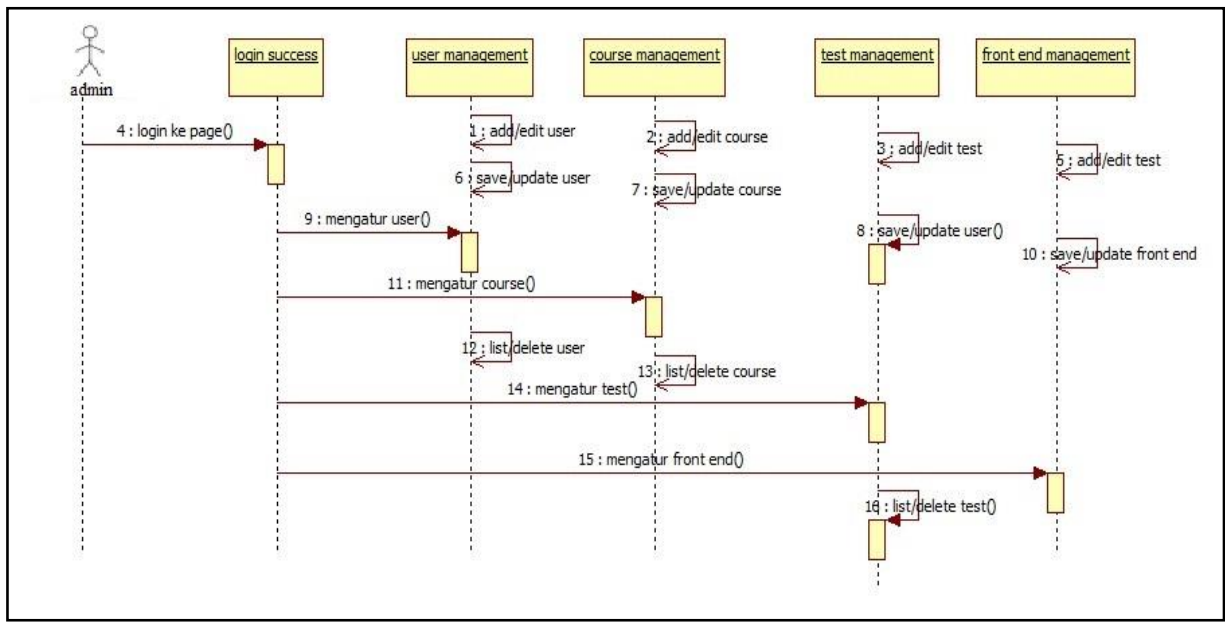

Gambar 9 Sequence Diagram Admin

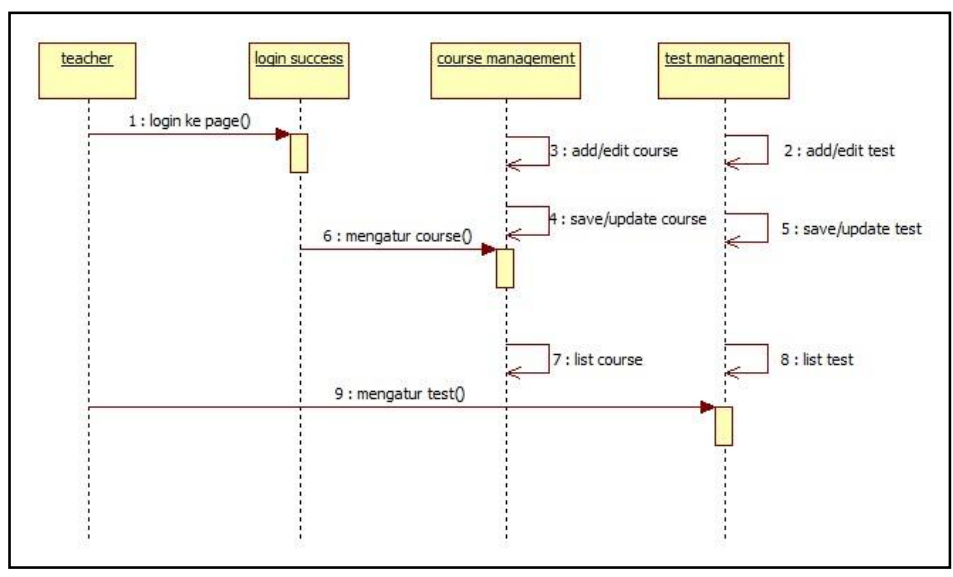

Gambar 10 Sequence Diagram Guru (Teacher)

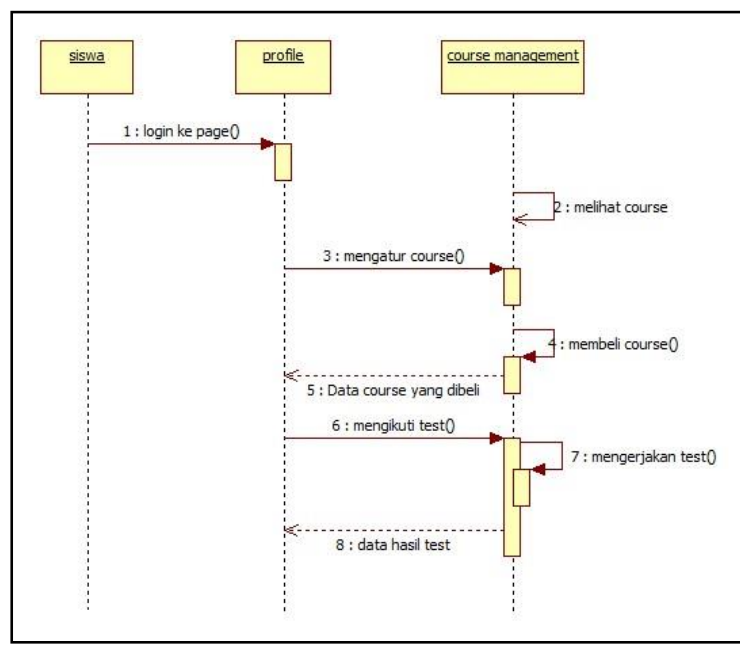

Gambar 11 Sequence Diagram Siswa (Murid)

\section{b. Rancangan Basis Data}


Agar suatu system berjalan dengan baik,maka harus dirancang dengan baik pula. Rancangan system berupa penggambaran dari komponen perangkat lunak dan perangkat keras pada suatu system. Dalam perancangan data di dalam aplikasi aplikasi system manajement belajar di growth2tech yang penulis buat adalah dengan membuat basis data sesuai dengan kebutujan data perangkat aplikasi tersebut

\section{1) Relasi Tabel}

Relasi Tabel merupakan hubungan antar table yang menghubungkan antar objrk yang berfungsi mengatur suatu operasi database.

\begin{tabular}{|c|c|c|c|}
\hline 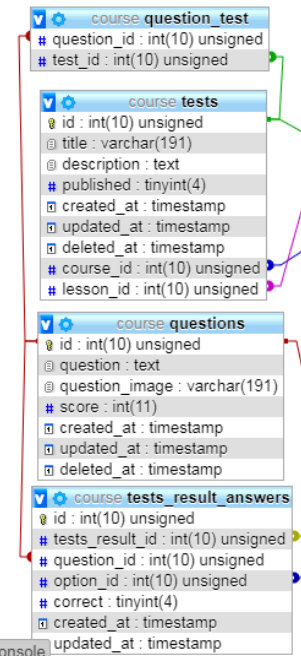 & 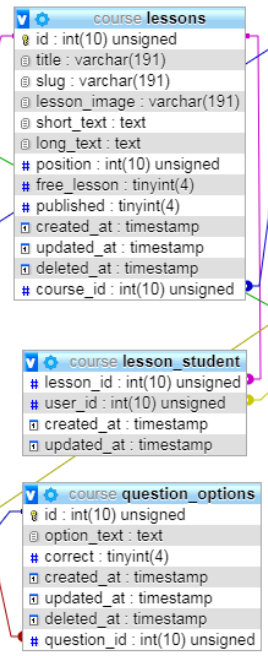 & 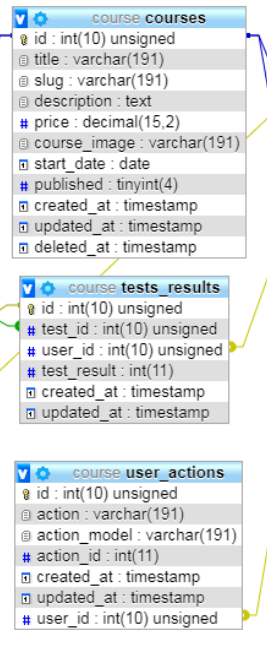 & 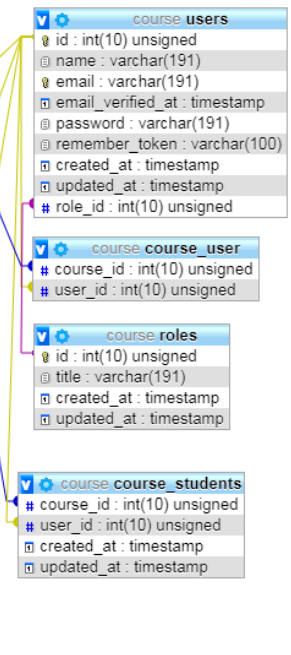 \\
\hline
\end{tabular}

Gambar 12 Relasi tabel

Tabel users, tabel ini merupakan tabel master informasi tentang user pada sistem.

Tabel courses, tabel ini berisi course yang akan ditampilkan ataupun dijual yang

Tabel course_students ini berisi course yang dibeli oleh siswa

Tabel course_user ini berisi course yang dibuat oleh user

Tabel lesson ini berisi materi yang akan ditampilkan

Tabel lesson_student ini berisi data seberapa jauh lesson yang diikuti oleh siswa

Tabel migration ini berisi data perubahan database menggunakan Laravel Tabel question ini berisi data pertanyaan yang di ajukan

Tabel question_options ini berisi data pilihan ganda terhadap tabel question Tabel question_test ini berisi letak dimana question dipasang

Tabel roles ini berisi data role yang dimiliki system

Tabel tests ini berisi data test yang akan ditampilkan pada lesson

Tabel test_results ini berisi data hasil dari test yang diikuti siswa

Tabel test_result_answer ini berisi data hasil test yang dijawab oleh siswa Tabel user_action ii merupakan data yang berisi record perubahan data yang dilakukan oleh user. 


\section{2) Data Dictionary}

Berdasarkan acuan dari system yang telah dirancang, maka dibutuhkan table-tabel yang akan menghasilkan kebutuhan untuk data yang akan digunakan pada system. Berikut table-table yang dirancang :

a) Users

$\begin{array}{ll}\text { Media } & \text { :Hard Disk } \\ \text { Isi } & : \\ \text { Primary Key } & : \text { id } \\ \text { Struktur } & :\end{array}$

Tabel 1 users

\begin{tabular}{|c|c|c|c|c|}
\hline No & Nama Field & Jenis & Lebar Desimal & Keterangan \\
\hline 1 & Id & integer & 10 & Primary key \\
\hline 2 & Name & text & & Nama user \\
\hline 3 & Email & text & & Email(FK) \\
\hline 4 & email_veritified_at & timestamp & & Vertifikasi \\
\hline 5 & password & text & & Password \\
\hline 6 & remember_token & varchar & 100 & Token \\
\hline 7 & created_at & timestamp & & Tanggal dibuat \\
\hline 8 & update_at & timestamp & & Tanggal diedit \\
\hline 9 & role_id & integer & 10 & Foreign key \\
\hline
\end{tabular}

\section{b) courses}

$\begin{array}{ll}\text { Media } & : \text { Hard Disk } \\ \text { Isi } & : \\ \text { Primary key } & : \text { id }\end{array}$

Tabel 2 courses

\begin{tabular}{|c|c|c|c|c|c|}
\hline No & Nama Field & Jenis & Lebar & Desimal & Keterangan \\
\hline 1 & Id & Integer & 10 & & Primary key \\
\hline 2 & Title & Text & & & Judul course \\
\hline 3 & Slug & Text & & & $\begin{array}{l}\text { Singkatan nama } \\
\text { Web dari course }\end{array}$ \\
\hline 4 & description & Text & & & Deskripsi course \\
\hline 5 & Price & Decimal & 15 & 2 & Harga course \\
\hline 6 & course_image & Text & & & $\begin{array}{l}\text { Alamat gambar } \\
\text { course }\end{array}$ \\
\hline 7 & start_date & Date & & & $\begin{array}{ll}\text { Tanggal course } \\
\text { dimulai }\end{array}$ \\
\hline 8 & Published & Tinyint & 4 & & Boolant \\
\hline 9 & created_at & timestamp & & & Tanggal dibuat \\
\hline 10 & update_at & timestamp & & & Tanggal update \\
\hline 11 & delete_at & timestamp & & & Tanggal didelete \\
\hline
\end{tabular}


c) course_students

$\begin{array}{ll}\text { Media } & : \text { Hard Disk } \\ \text { Isi } & : \\ \text { Primary key } & : \text { id }\end{array}$

Tabel 3 courses_students

\begin{tabular}{cccccc}
\hline No & Nama Field & Jenis & Lebar & Desimal & Keterangan \\
\hline 1 & course_id & integer & 10 & foreign key \\
\hline 2 & user_id & integer & 10 & foreign key \\
\hline 3 & created_at & timestamp & & & Tanggal dibuat \\
\hline 4 & update_at & timestamp & & Tanggal di update \\
\hline
\end{tabular}

d) course_user

$\begin{array}{ll}\text { Media } & : \text { Hard Disk } \\ \text { Isi } & : \\ \text { Primary key } & : \text { id }\end{array}$

Tabel 4 courses_user

\begin{tabular}{cccccc}
\hline No & Nama Field & Jenis & Lebar & Desimal & Keterangan \\
\hline 1 & course_id & integer & 10 & foreign key \\
\hline 2 & user_id & integer & 10 & foreign key \\
\hline 3 & created_at & timestamp & & Tanggal dibuat \\
\hline 4 & update_at & timestamp & & & Tanggal diupdate \\
\hline
\end{tabular}

e) lessons

Media : Hard Disk

Isi :

Primary key $\quad$ : id

Tabel 5 lessons

\begin{tabular}{|c|c|c|c|c|c|}
\hline No & Nama Field & Jenis & Lebar & Desimal & Keterangan \\
\hline 1 & Id & Integer & 10 & & Primary key \\
\hline 2 & Title & Text & & & Judul Lesson \\
\hline 3 & Slug & Text & & & $\begin{array}{l}\text { Singkatan } \\
\text { nama Web } \\
\text { dari lesson }\end{array}$ \\
\hline 4 & $\begin{array}{c}\text { Lesson_ima } \\
\text { ge }\end{array}$ & Text & & & $\begin{array}{c}\text { Gambar } \\
\text { lesson }\end{array}$ \\
\hline 5 & Short_text & Text & & & $\begin{array}{c}\text { Summary } \\
\text { lesson }\end{array}$ \\
\hline 6 & Long_text & Text & & & Isi dari lesson \\
\hline 7 & Position & Integer & 10 & & Posisi lesson \\
\hline 8 & Free_lesson & Tinyint & 4 & & $\begin{array}{c}\text { Boolan gratis } \\
\text { atau tidak }\end{array}$ \\
\hline 9 & Published & Tinyint & 4 & & $\begin{array}{c}\text { Boolan } \\
\text { ditampangka } \\
\mathrm{n} \text { atau tidak }\end{array}$ \\
\hline 10 & Created_at & Timesta & & & Tanggal \\
\hline
\end{tabular}




\begin{tabular}{clcc}
\hline & & $\mathrm{mp}$ & dibuat \\
\hline 11 & Update_at & $\begin{array}{c}\text { Timesta } \\
\mathrm{mp}\end{array}$ & $\begin{array}{c}\text { Tanggal } \\
\text { diupdate }\end{array}$ \\
\hline 12 & Delete_at & $\begin{array}{c}\text { Timesta } \\
\mathrm{mp}\end{array}$ & $\begin{array}{c}\text { Tanggal } \\
\text { dihapus }\end{array}$ \\
\hline 13 & Course_id & Integer $\quad 10$ & Foreign key \\
\hline f) & lesson_studens & & \\
& Media & : Hard Disk & \\
& Isi & $:$ & \\
& Primary key & $:$ id &
\end{tabular}

Tabel 6 lesson_students

\begin{tabular}{llllll}
\hline No & Nama Field & Jenis & Lebar & Desimal & Keterangan \\
\hline 1 & Lesson_id & Integer & 10 & Foreign key \\
\hline 2 & User_id & integer & 10 & Foreign key \\
\hline 3 & Created_at & Timestamp & & Tanggal dibuat \\
\hline 4 & Update_at & timestamp & & $\begin{array}{l}\text { Tanggal } \\
\text { diupdate }\end{array}$ \\
\hline
\end{tabular}

g) migration

Media

Isi

Primary key
: Hard Disk

: id

Tabel 7 migration

\begin{tabular}{cccccc}
\hline No & Nama Field & Jenis & Lebar & Desimal & Keterangan \\
\hline 1 & id & Integer & 10 & & Primary key \\
\hline 2 & Migration & Text & & Data migrate \\
\hline 3 & batch & intrger & 11 & Urutan data \\
\hline
\end{tabular}

h) questions

$\begin{array}{ll}\text { Media } & : \text { Hard Disk } \\ \text { Isi } & : \\ \text { Primary key } & : \text { id }\end{array}$

Tabel 8 questions

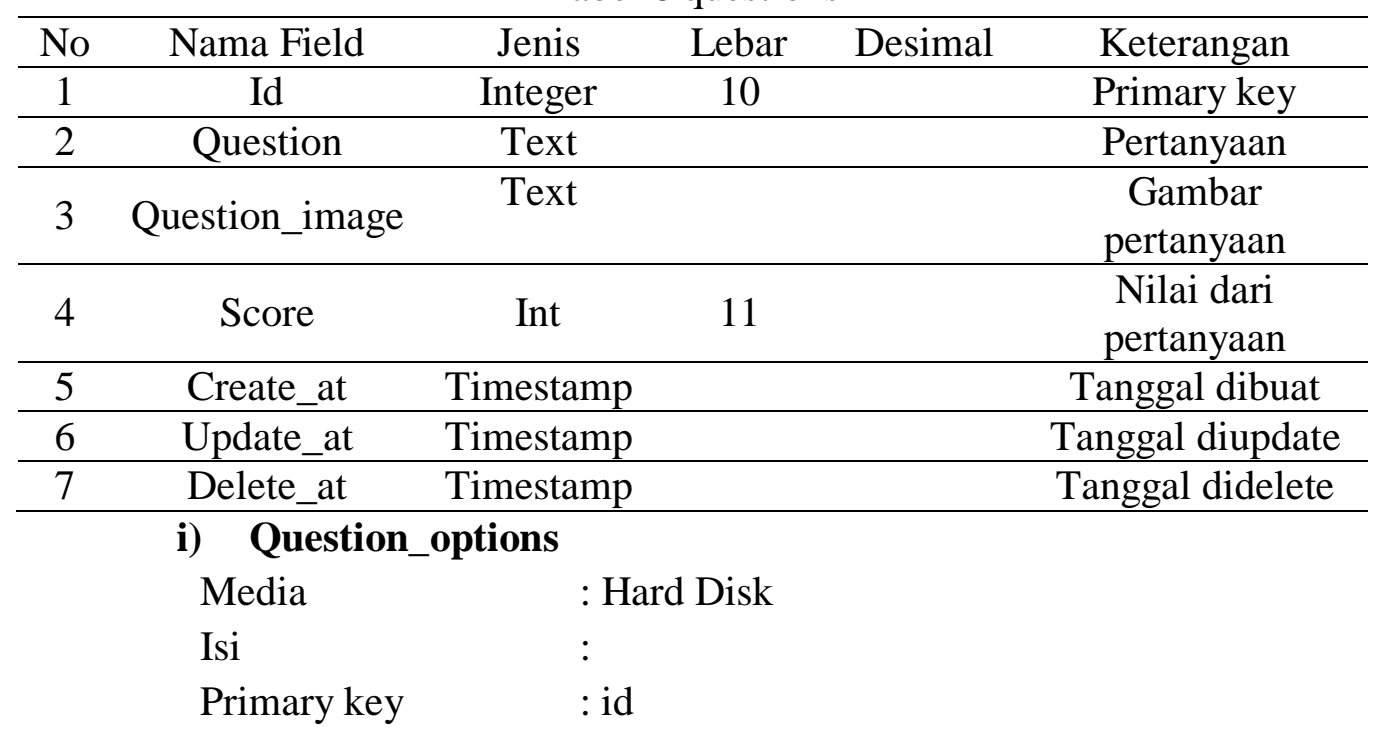


Ponsen Sindu Prawito dan Hardiansyah Putera Perdana

Tabel 9 question_options

\begin{tabular}{|c|c|c|c|c|}
\hline No & Nama Field & Jenis & Desimal & Keterangan \\
\hline 1 & Id & Integer & 10 & Primary key \\
\hline 2 & Option_text & Text & & Opsi pilihan ganda \\
\hline 3 & Correct & Tinyint & 4 & $\begin{array}{c}\text { Opsi yang benar } \\
\text { atau salah }\end{array}$ \\
\hline 4 & Created_at & Timestamp & & Tanggal dibuat \\
\hline 5 & Update_at & Timestamp & & Tanggal diupdate \\
\hline 6 & Delete_at & Timestamp & & Tanggal didelete \\
\hline 7 & Question_id & Integer & 10 & Foreign key \\
\hline \multicolumn{5}{|c|}{ j) Question_test } \\
\hline & \multicolumn{2}{|c|}{ Media } & \multirow{2}{*}{\multicolumn{2}{|c|}{ : Hard Disk }} \\
\hline & \multicolumn{2}{|l|}{ Isi } & & \\
\hline & \multicolumn{2}{|c|}{ Primary key } & : id & \\
\hline
\end{tabular}

Tabel 10 question_test

\begin{tabular}{cccccc}
\hline No & Nama Field & Jenis & Lebar & Desimal & Keterangan \\
\hline 1 & Question_id & Integer & 10 & & Foreign key \\
\hline 2 & Test_id & integer & 10 & & Foreign key \\
\hline
\end{tabular}

k) roles

$\begin{array}{ll}\text { Media } & : \text { Hard Disk } \\ \text { Isi } & : \\ \text { Primary key } & : \text { id }\end{array}$

Tabel 11 roles

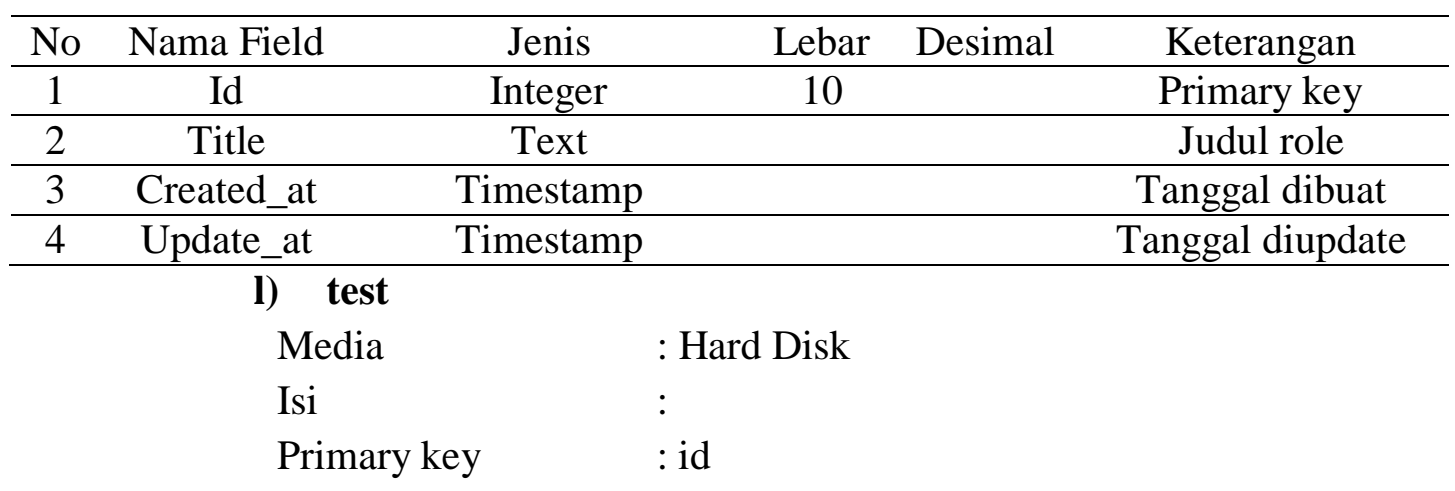

Tabel 12 test

\begin{tabular}{cccccc}
\hline No & Nama Field & Jenis & Lebar & Desimal & Keterangan \\
\hline 1 & Id & Integer & 10 & Primary key \\
\hline 2 & title & Text & & Judul test \\
\hline 3 & Description & Text & & Penjelasan test \\
\hline 4 & Published & Tinyint & 4 & $\begin{array}{c}\text { Dimunjulkan atau } \\
\text { tidak }\end{array}$ \\
\hline 5 & Created_at & Timestamp & Tanggal dibuat \\
\hline
\end{tabular}




\begin{tabular}{|c|c|c|c|}
\hline 6 & Update_at & Timestamp & Tanggal diupdate \\
\hline 7 & Delete_at & Timestamp & Foreign key \\
\hline 8 & Course_id & Integer & Foreign key \\
\hline 9 & Lesson_id & Integer & Foreign key \\
\hline \multicolumn{4}{|c|}{ m) test_results } \\
\hline & Media & : Hard Disk & \\
\hline & Isi & : & \\
\hline & Prima & : id & \\
\hline
\end{tabular}

Tabel 13 test_results

\begin{tabular}{|c|c|c|c|c|c|}
\hline No & Nama Field & Jenis & Lebar & Des & Keterangan \\
\hline 1 & Id & Integer & 10 & & Primary key \\
\hline 2 & Test_id & Integer & 10 & & Foreign key \\
\hline 3 & User_id & Integer & 10 & & Foreign key \\
\hline 4 & Test_result & Integer & 11 & & Hasil test \\
\hline 5 & Created_at & Timestamp & & & Tanggal dibuat \\
\hline 6 & Update_at & Timestamp & & & $\begin{array}{l}\text { Tanggal } \\
\text { diupdate }\end{array}$ \\
\hline
\end{tabular}

n) test_results_answers

$\begin{array}{ll}\text { Media } & : \text { Hard Disk } \\ \text { Isi } & : \\ \text { Primary key } & : \text { id }\end{array}$

Tabel 14 test_results_answers

\begin{tabular}{llllll}
\hline No & Nama Field & Jenis & Lebar & Desimal & Keterangan \\
\hline 1 & Id & Integer & 10 & & Primary key \\
\hline 2 & Tests_result_id & Integer & 10 & Foreign key \\
\hline 3 & Question_id & Integer & 10 & Foreign key \\
\hline 4 & Option_id & Integer & 10 & Foreign key \\
\hline 5 & Correct & Tinyint & 4 & Jawaban benar \\
\hline 6 & Created_at & Timestamp & & Tanggal dibuat \\
\hline 7 & Updated_at & timestamp & Tanggal diupdate \\
\hline \multicolumn{5}{c}{ o) $\quad$ user_action } \\
Media \\
Isi \\
Primary key
\end{tabular}

Tabel 15 user_action

\begin{tabular}{llllll}
\hline No & Nama Field & Jenis & Lebar & Desimal & Keterangan \\
\hline 1 & Id & Integer & 10 & Primary key & \\
\hline 2 & Action & Text & & Action yang dilakukan user \\
\hline 3 & Action_model & Text & & $\begin{array}{l}\text { Action model apa yang } \\
\text { dirubah }\end{array}$ & \\
\hline 4 & Action_id & Integer & 11 & Action id & \\
\hline 5 & Created_at & Timestamp & Tanggal dibuat & \\
\hline 6 & Update_at & Timestamp & Tanggal update \\
\hline 7 & User_id & Integer & 10 & Foreign key & \\
\hline
\end{tabular}




\section{c. Rancangan Keluaran}

Keluaran merupakan hasil dari pengolahan data yang diterima dari proses masukan data berupa informasi yang berguna bagi pengguna. Adapun rancangan aplikasi system manajemen belajar di Growth2tech sebagai berikut :

1) Rancangan Keluaran Laporan Hasil Transaksi

Rancangan Keluaran Hasil transaksi ini berupa laporan dari setiap pembelian course yang dilakukan oleh $u$ ser

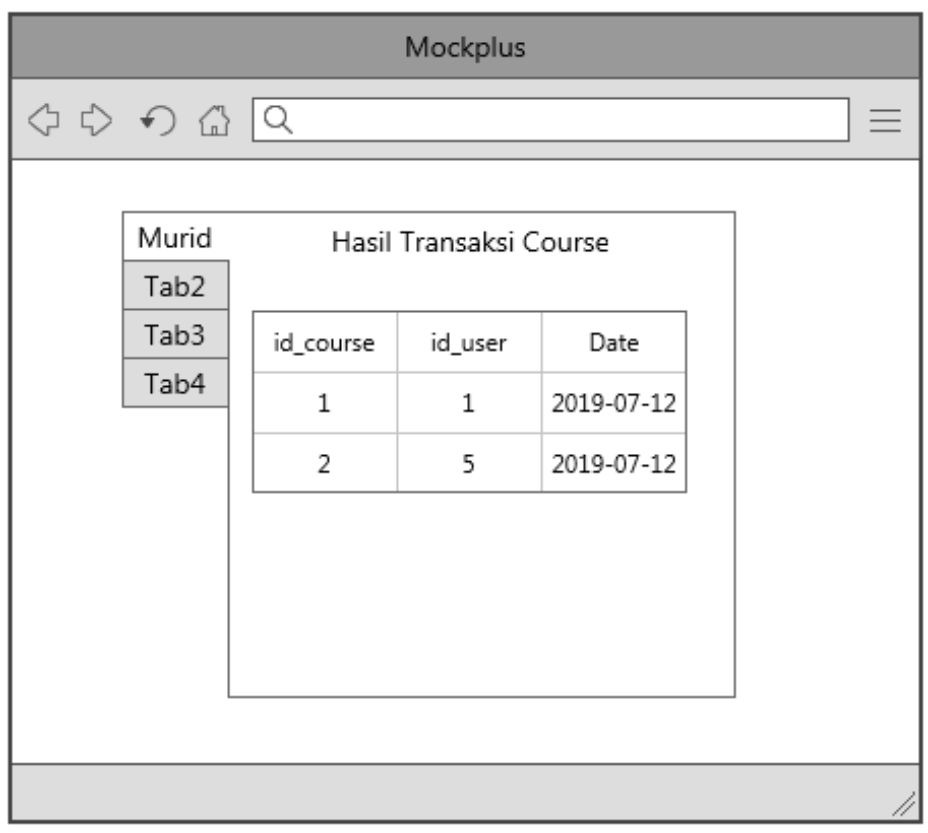

Gambar 13 Rancangan hasil transaksi

2) Rancangan Keluaran Laporan Aktifitas Manajemen Belajar

Rancangan keluaran laporan transaksi ini berupa data laporan dari semua perubahan pada manajemen belajar ini

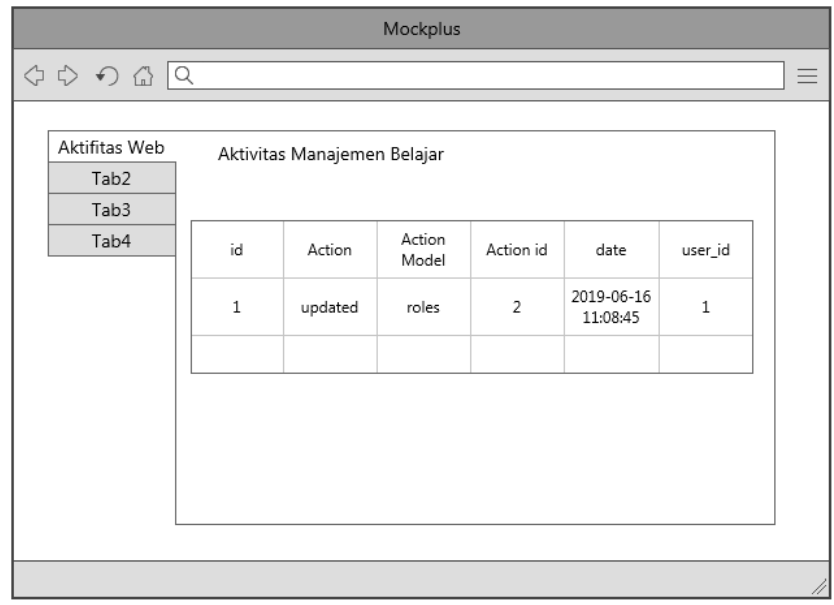

Gambar 14 Rancangan Laporan Aktivitas manajemen

3) Rancangan Keluaran Laporan kursus (Course) 
Rancangan Keluaran Laporan kursus (Course) ini berupa data laporan dari semua course yang tersimpan

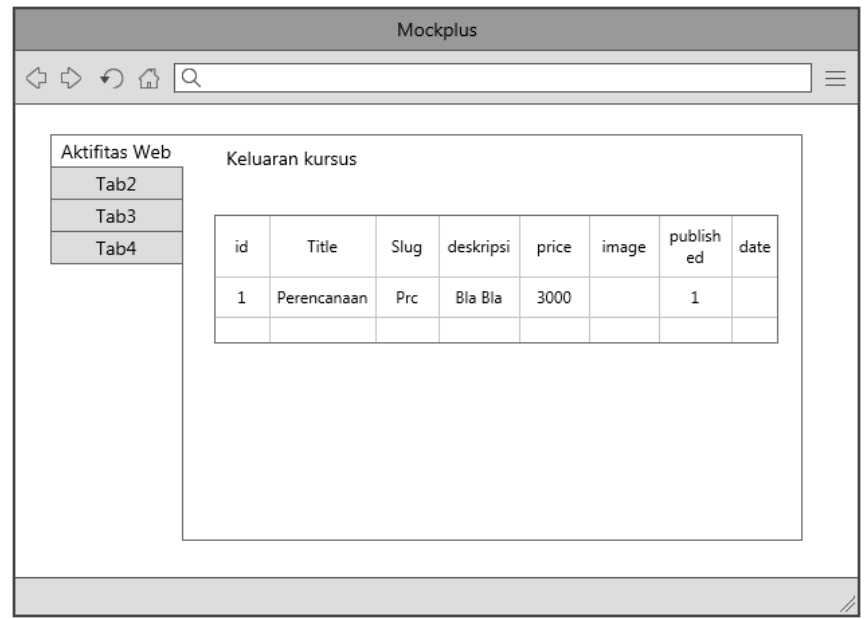

Gambar 15 Rancangan Laporan Course/kursus

\section{d. Rancangan Masukan}

Masukan atau inputan merupakan awal dari mulainya proses informasi. Bahan mentah dari informasi adalah data yang terjadi dari transaksi atau kegiatan yang dilakukan oleh Admin. Data dari hasil transaksi atau kegiatan tersebut merupakan data untuk memperoleh suatu informasi, Adapun rancangan masukan aplikasi system manajemen belajar di Growth2tech sebagai berikut :

1) Rancangan Masukan pada admin panel

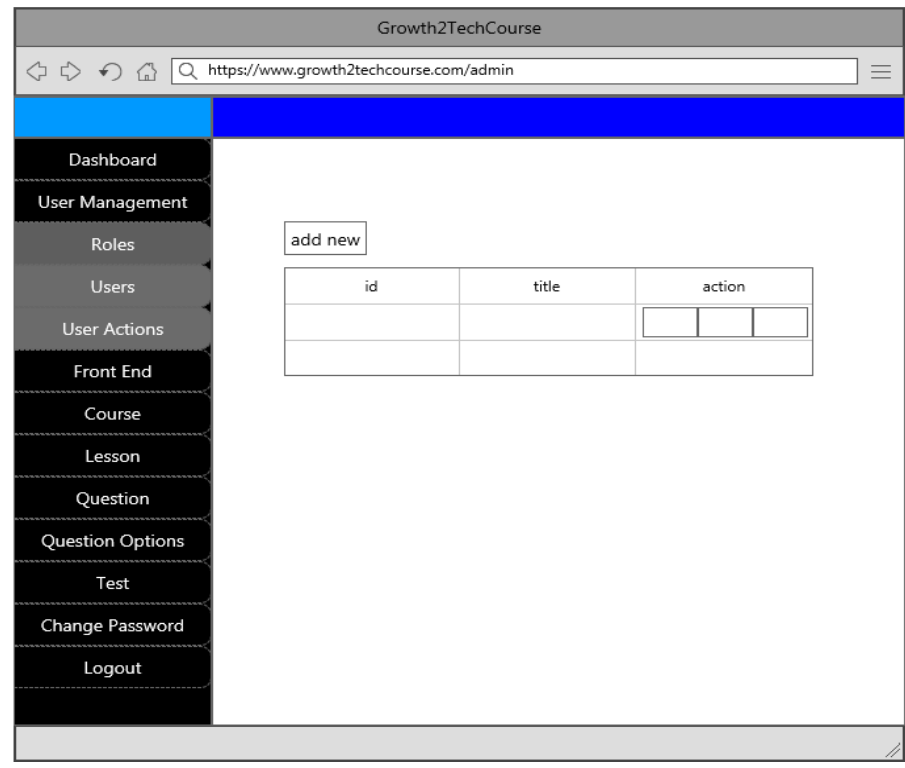

Gambar 16 Rancangan admin panel (role admin)

Gambar 16 adalah rancangan ui admin pada saat melakukan control pada sistem saat pengguna ingin mengubah data yang ada pada website atau mengubah tanpilab pada website. 
2) Rancangan Masukan pada Index

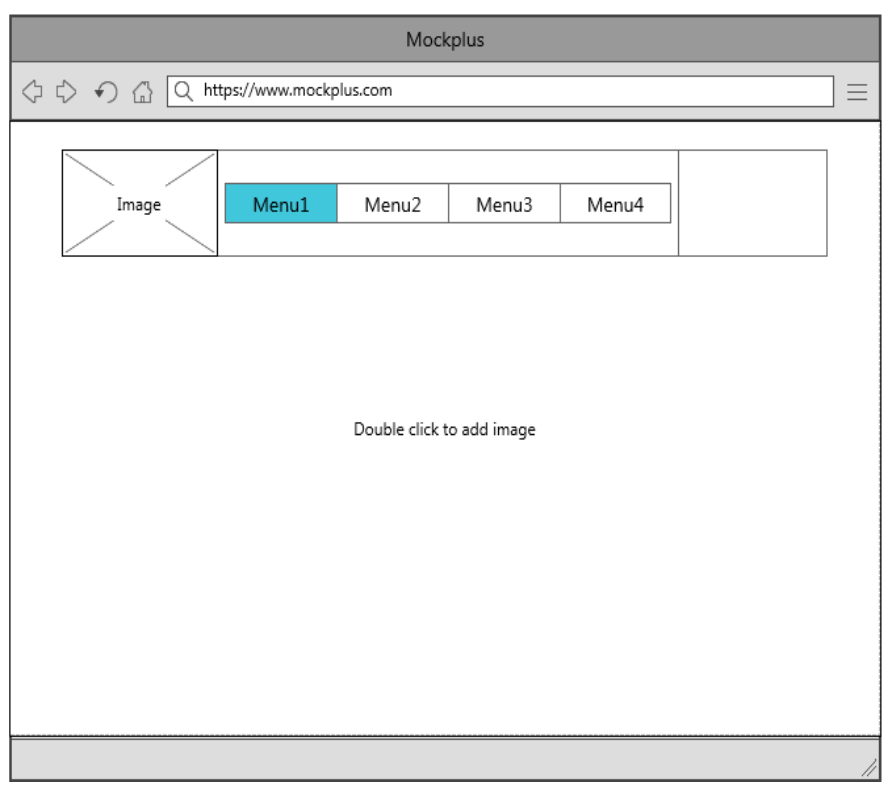

Gambar 17 Rancangan index

Diatas adalah rancangan ui bagian awal dari website pada saat pertama kali dibuka.

3) Rancangan Masukan pada Login

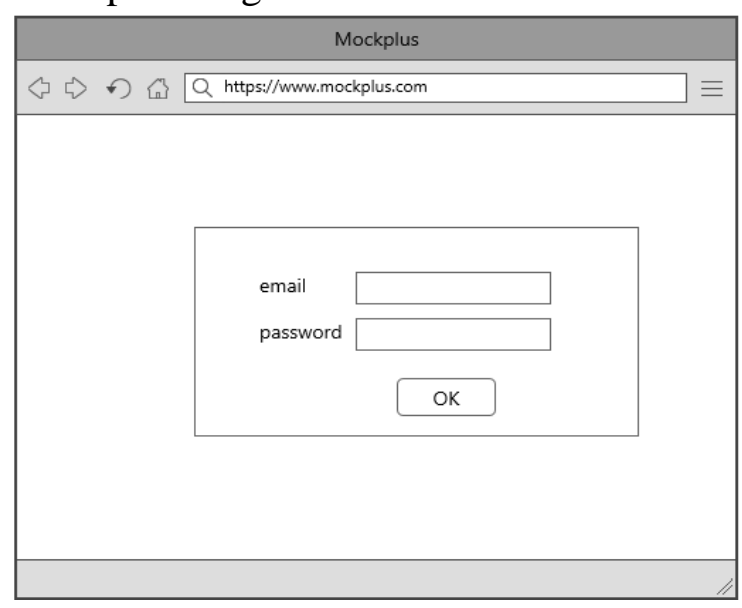

Gambar 18 Rancangan login

Gambar di atas adalah rancangan login dimana semua user login untuk masuk ke sistem. 
4) Rancangan Masukan pada Login

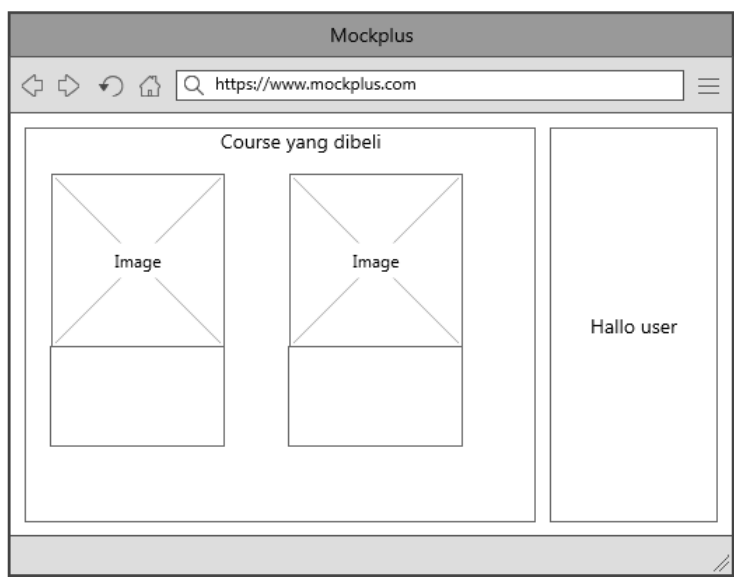

Gambar 19 Rancangan Profile

Gambar 19 adalah rancangan profile yang dimana bisa dilihat bila anda seorang siswa di sistem ini

5) Rancangan Masukan pada Register

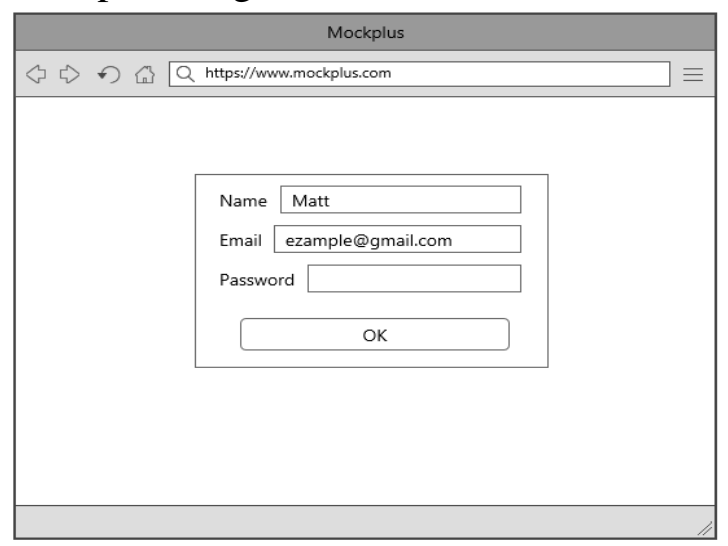

Gambar 20 Rancangan Register

6) Rancangan Masukan pada membeli course

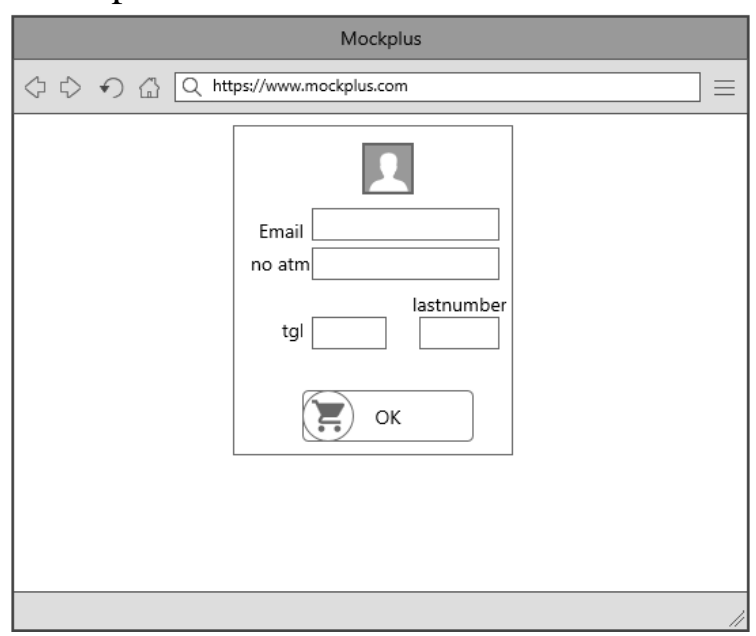


Gambar 21 Rancangan membeli course

e. Spesifikasi Hardware dan Software

1) Server

$\begin{array}{ll}\text { Processor } & : 1,6 \mathrm{GHz} \mathrm{CPU} \\ \text { 'RAM } & : 1.75 \mathrm{~GB} \\ \text { HDD } & : 1 \times 40 \mathrm{~GB} \\ \text { Koneksi Internet } & :>50 \mathrm{kbps} \\ \text { OS } & : \text { linux server }\end{array}$

2) Client

$\begin{array}{ll}\text { Processor } & : 233 \mathrm{MHz} \\ \text { RAM } & : 128 \mathrm{MB} \\ \text { Aplikasi } & : \text { Browser } \\ \text { Koneksi Internet } & :>50 \mathrm{kbps}\end{array}$

\section{f. Implemintasi Sistem}

Implementasi system merupakan kelanjutan dari suatu perancangan program dan dapat pula dipasang sebagai usaha untuk mewujubkan system yang telah dirancang dan merupakan tahap untuk meletakan system supaya siap untuk diimplementasikan pada instansi terkait.

\section{Batasan Implemintasi}

Aplikasi web ini hanya berfungsi untuk input course baru, update course, serta hapus course dan meliputi semua yang dibutuhkan course seperti test, jual-beli course dan sebagainya.

\section{a. Implemintasi Perangkat Lunak}

- Sistem Operasi

Sistem operasi yang minimal menggunakan Windows 764 - bit.

- Bahasa pemograman

Bahasa pemograman yang digunakan PHP,CSS, dan Javascript.

DBMS (Database Management System)

Menggunakan server portable laragon.

IDE (Integrated Development Environment)

IDE yang digunakan adalah Microsoft Visual Studio Code

\section{b. Implemintasi Instalasi Program}

Sebelum melakukan instalasi, sebaiknya mempersiapkan kebutuhankebutuhan yang diperlukan untuk kelangsungan instalasi. Pastikan komputer sudah terinstall Laragon dan semua paketnya terinstal. Pastikan computer sudah terinstal composer dan laravel. Copy semua file php yang dibutuhkan kedalam folder. C:Uaragon $\mid \mathbf{w w w}$. Buka command promt dan ganti directory ke C:laragonlwww $\backslash$ namaproject $\}$. Lalu tulis command composer install. Setelah itu rubah database sesuai dengan nama database yang dituju. Selanjutnya tulis 
command php artisan key:generate. Untuk mengisi database cukup migrate data yang sudah ada dengan menulis php artisan migrate

\section{c. Implemintasi Ujicoba sistem}

\section{1) Pengujian system}

Pengujian system dilakukan untuk memeriksa kekompakan antar komponen system yang diimplementasikan. Tujuan utama dari pengujian aplikasi adalah untuk memastikan bahwa komponen-komponen dari system telah berfungsi dengan baik. Pengujian yang digunakan adalah metode pengujian black box. Dimana pengujian blackboxini merupakan pengujian aspek fundamental system tanpa memperhitungkan aspek logika. Admin control pada aplikasi.

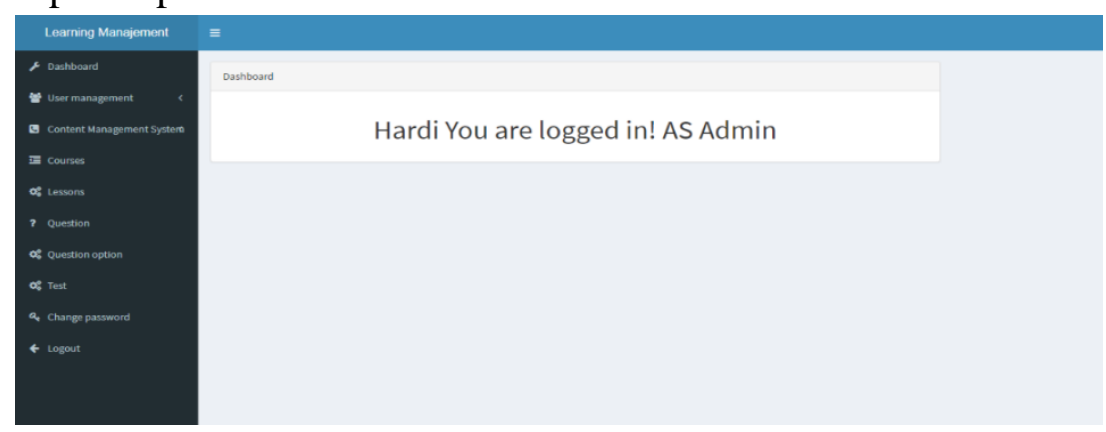

Gambar 24 admin panel (role admin)

Pada admin panel ini user mendapakan semua hak akses dalam mengatur web maupun frontend maupun backend dan dalam membuat course admin dapat memasukan lebih dari satu guru

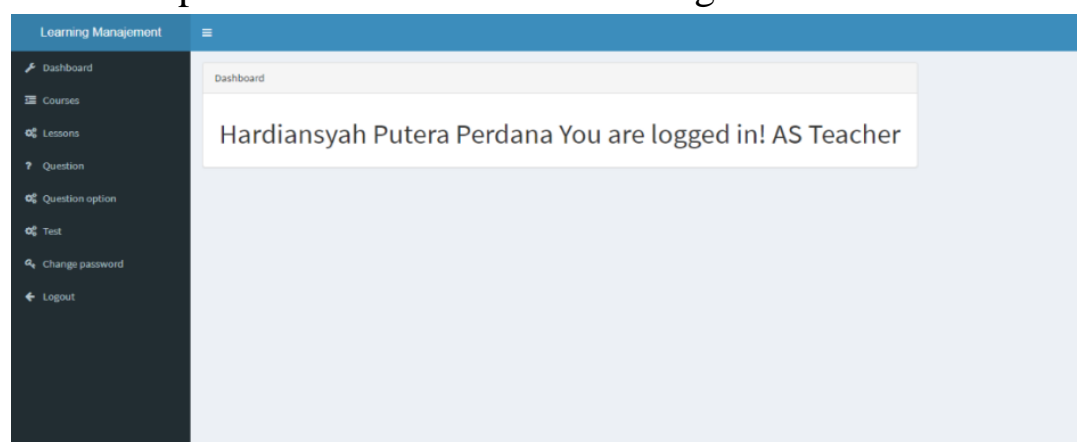

Gambar 25 admin panel (role teacher)

Pada admin panel diatas guru hanya dapat merubah course dan test saja dan hanya bisa memasukan course sesuai dengan id yang guru login:

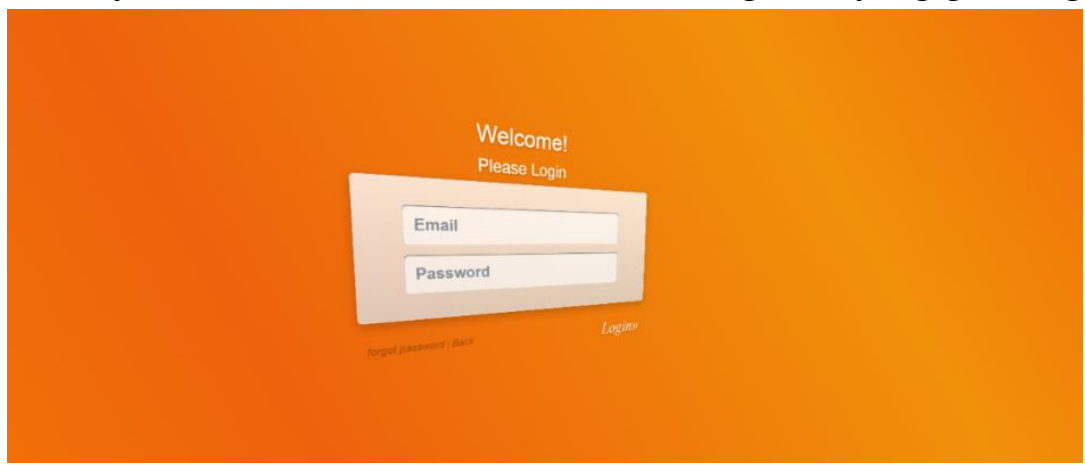


Gambar 26 Login

Login untuk semua user yang mau menggunakan aplikasi

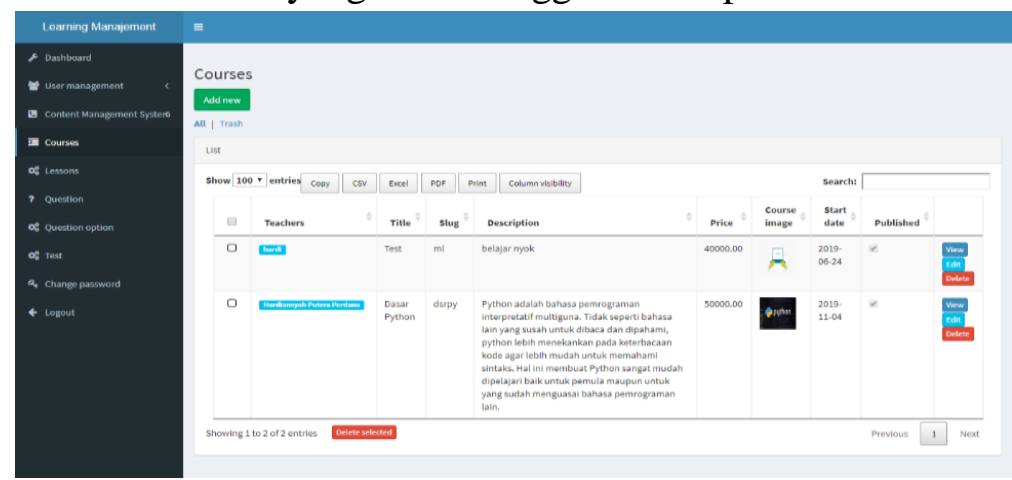

Gambar 27 Manajemen Course

Pada page ini user bisa mengatur isi course pada website

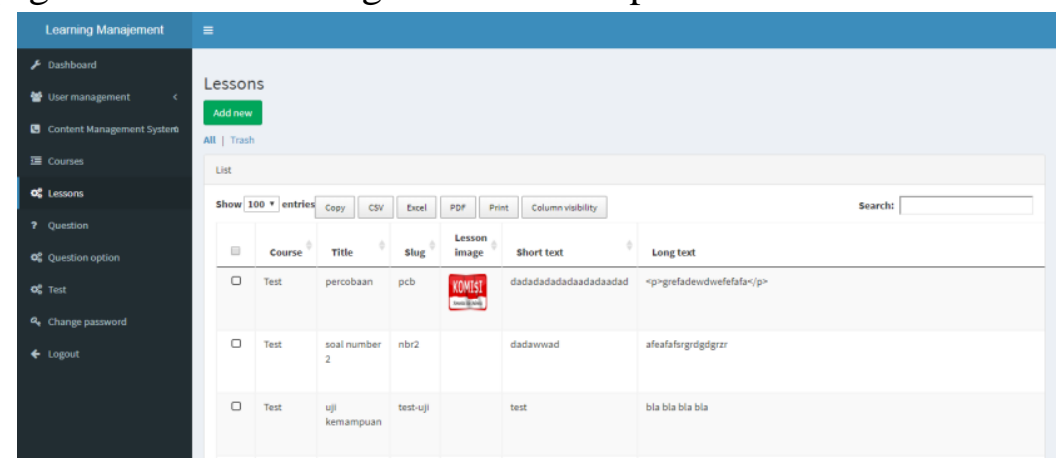

Gambar 28 Manajemen Lesson

Pada page ini user bisa mengatur isi course yaitu lesson pada website

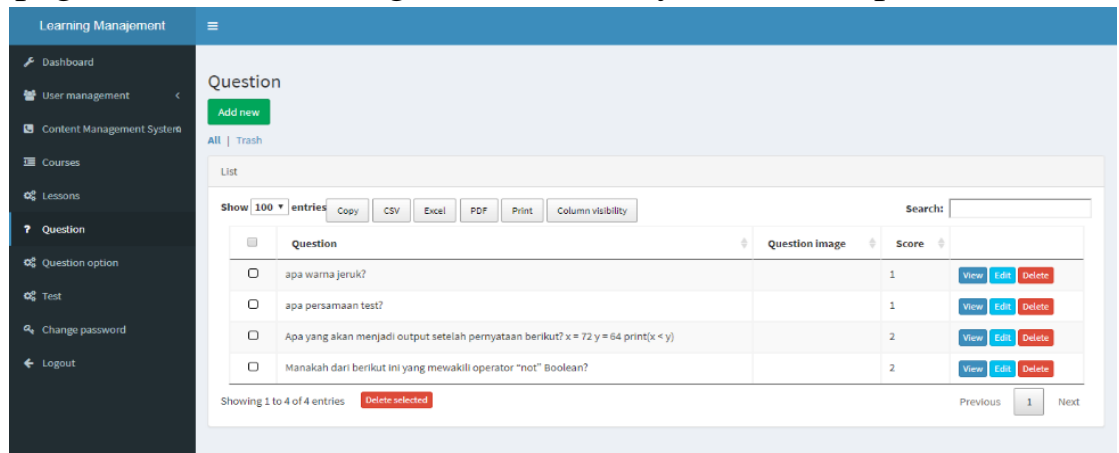

Gambar 29 Manajemen question

Gambar diatas adalah WEB page yang berfungsi untuk memanajemen isi lesson yaitu question 


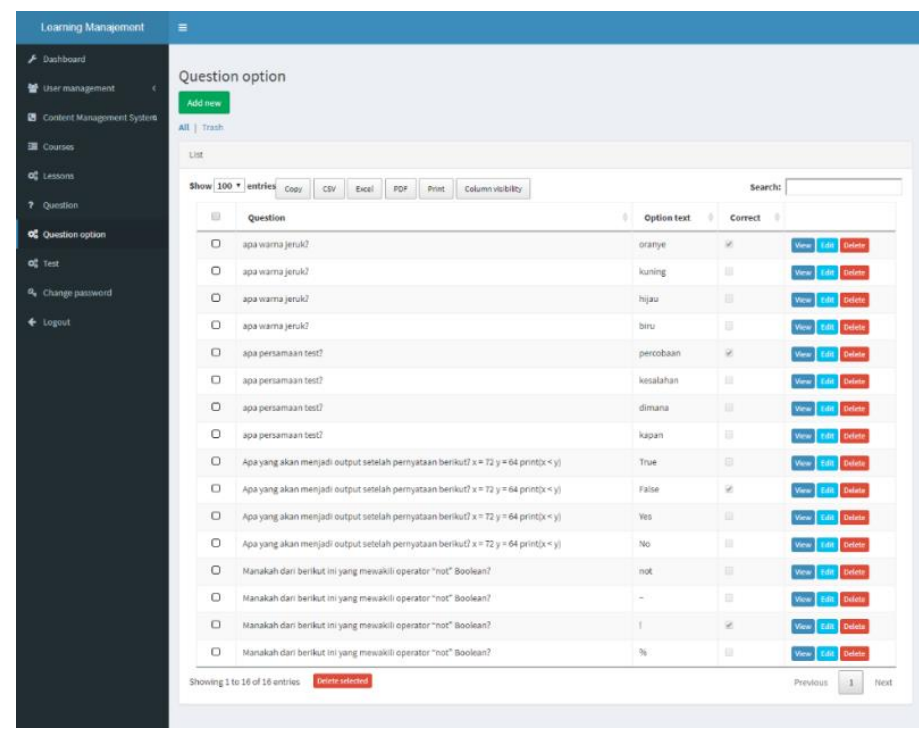

Gambar 30 Manajemen question option

Gambar diatas adalah WEB page yang berfungsi untuk memanajemen isi question yaitu question option

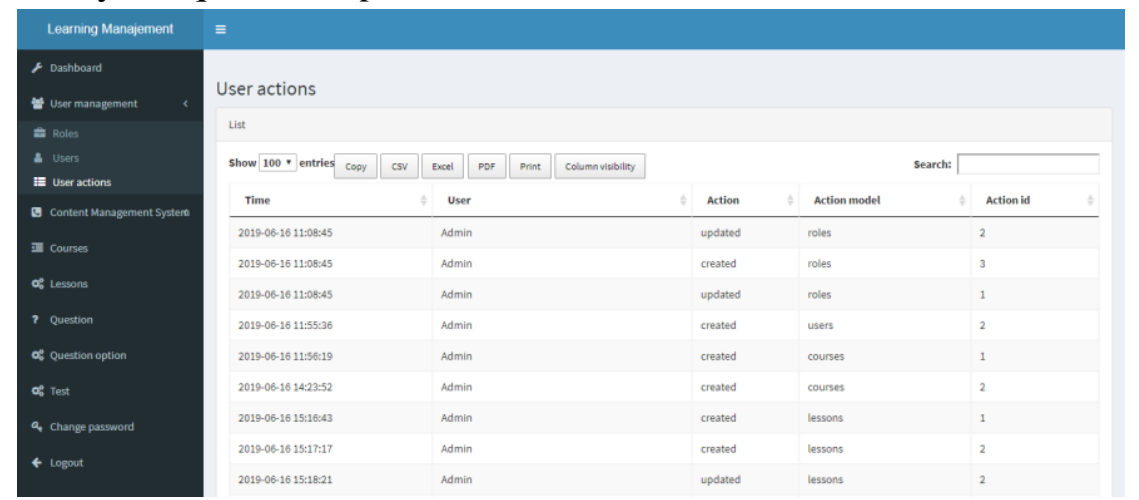

Gambar 31 User actions

Gambar diatas adalah web page berfungsi untuk melihat dan mengawasi perubahan website yang dilakukan user

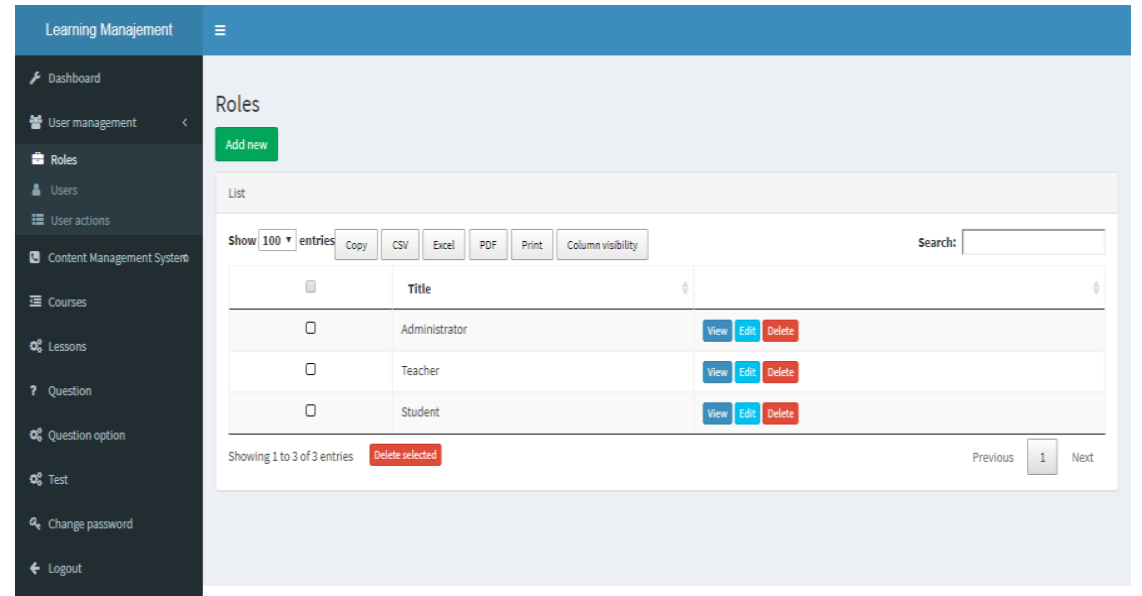

Gambar 32 User Role

Gambar diatas adalah page web berfungsi untuk manajemen role yang ada di website 


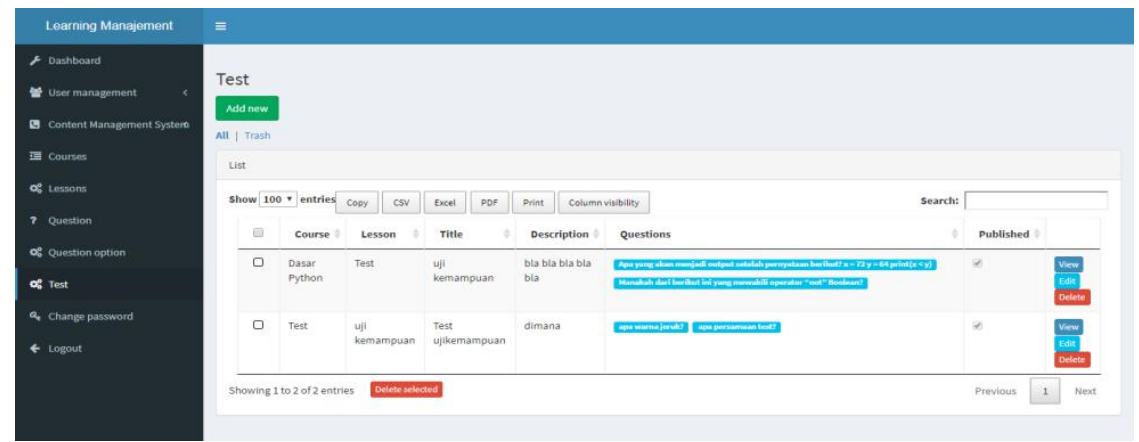

Gambar 33 Test

Gambar diatas adalah WEB page yang berfungsi untuk memanajemen isi lesson yaitu Test dan berhubungan dengan question yang sudah dibuat
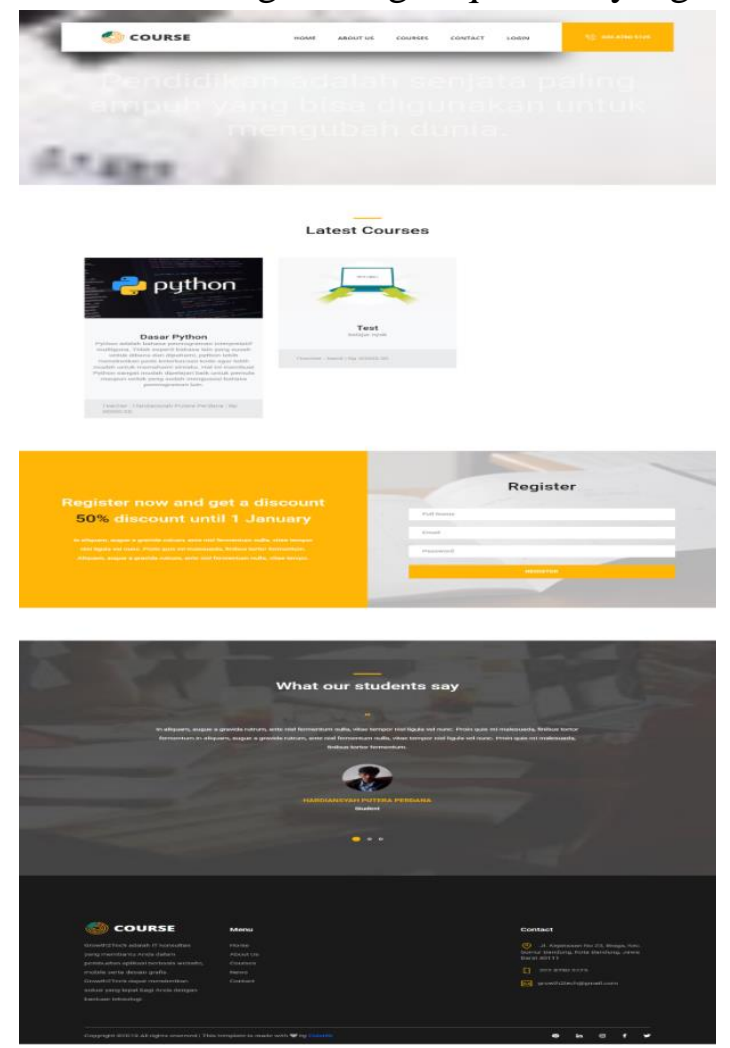

Gambar 34 Home page

Gambar diatas adalah home page yang berfungsi untuk tampilan awal sebuah website dan pendaftaran siswa baru dan memperlihatkan course terbaru pada user baru 
Ponsen Sindu Prawito dan Hardiansyah Putera Perdana

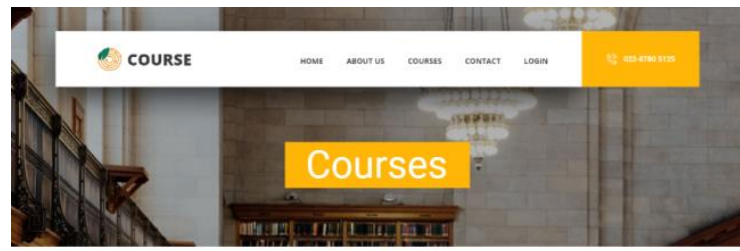

Popular Courses

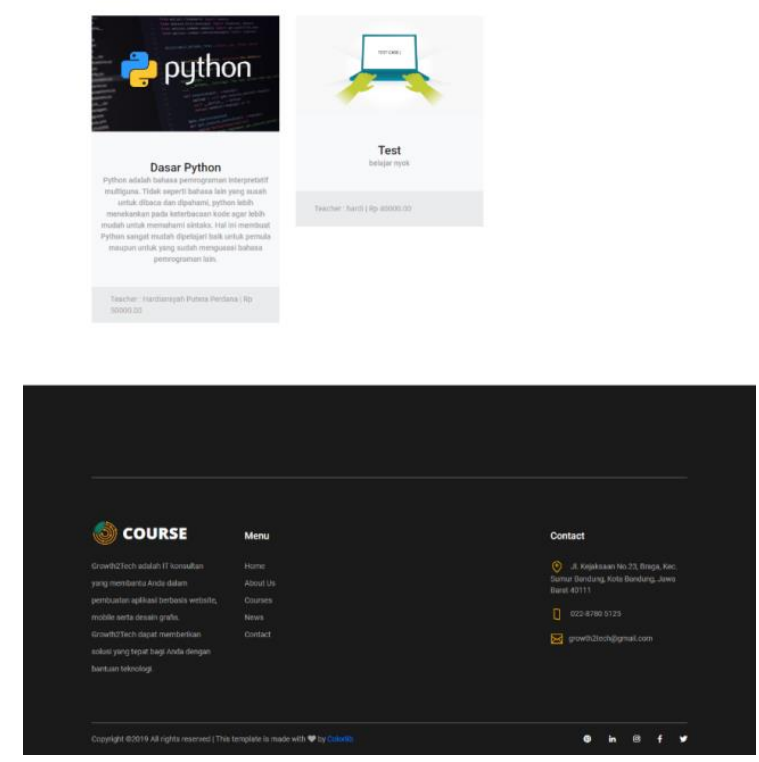

Gambar 35 Course page

Gambar diatas adalah course page yang berfungsi untuk menampilkan semua course yang ada di website
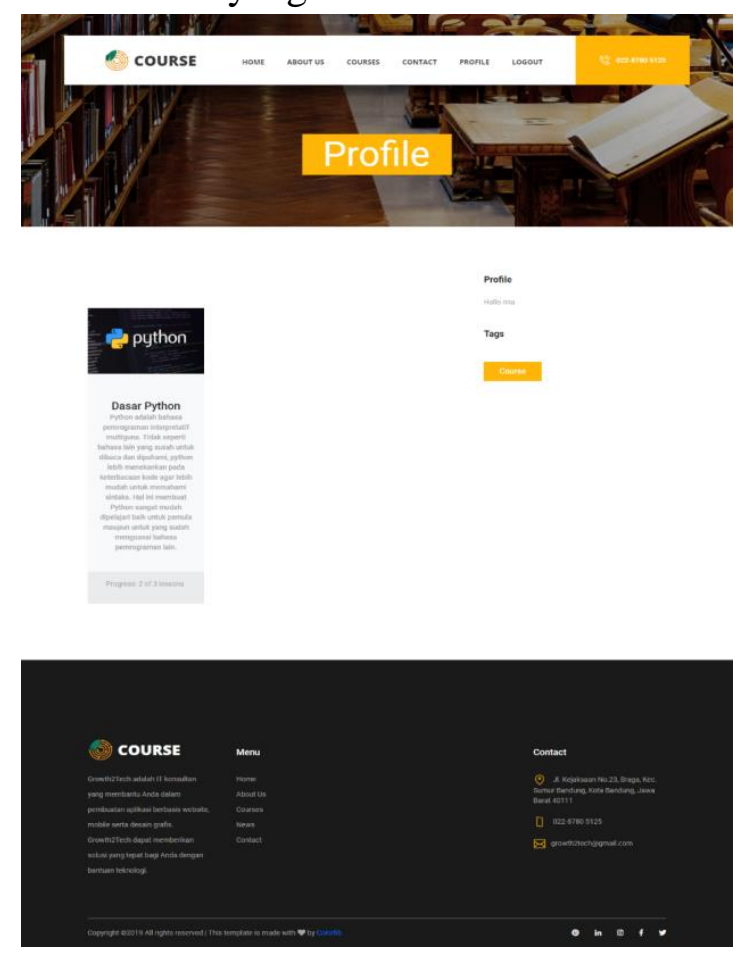

Gambar 36 Profile page 
Gambar diatas adalah Profile page yang berfungsi untuk menampilkan semua course yang sudah dibeli siswa dan menampilkan nama siswa yang login di website

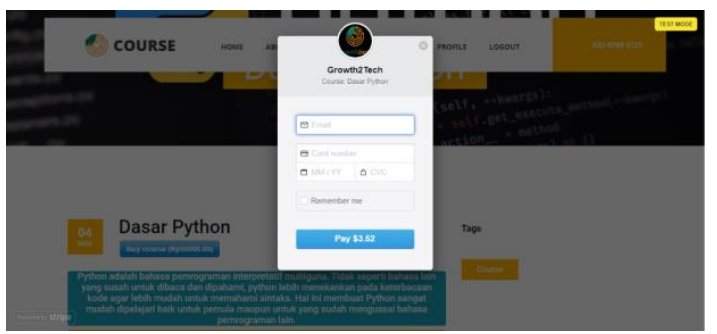

Gambar 37 payment

Gambar diatas adalah Payment disini user membeli course dan membayar dengan kartu debit/credit dengan api stripe dengan mengisi kolom kosong pada form
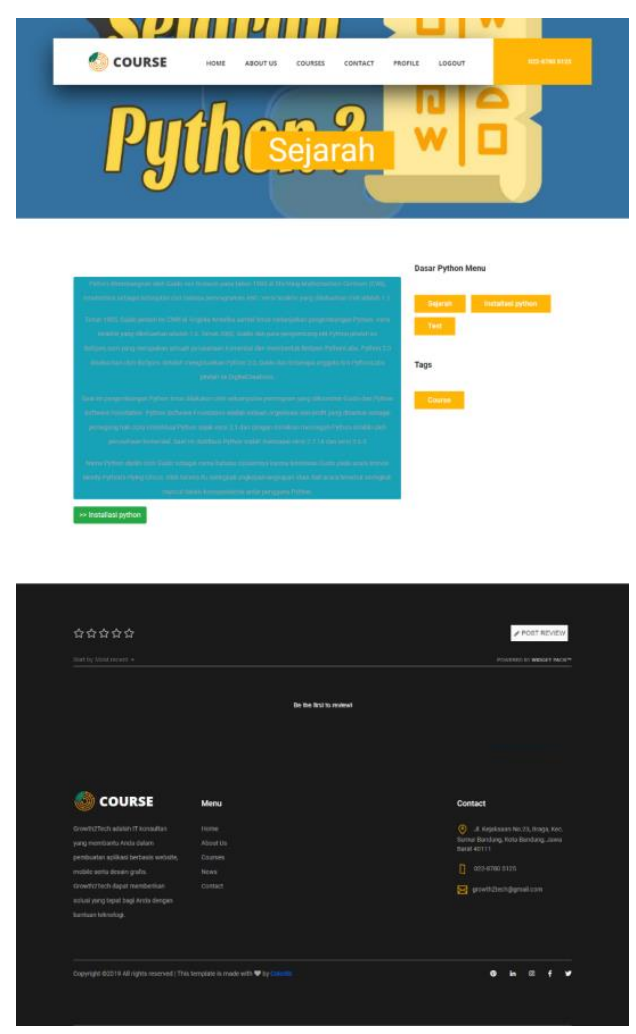

Gambar 38 Lesson Page

Gambar diatas adalah lesson page disini user belajar course sesuai menu lesson yang berrada di dalam course 


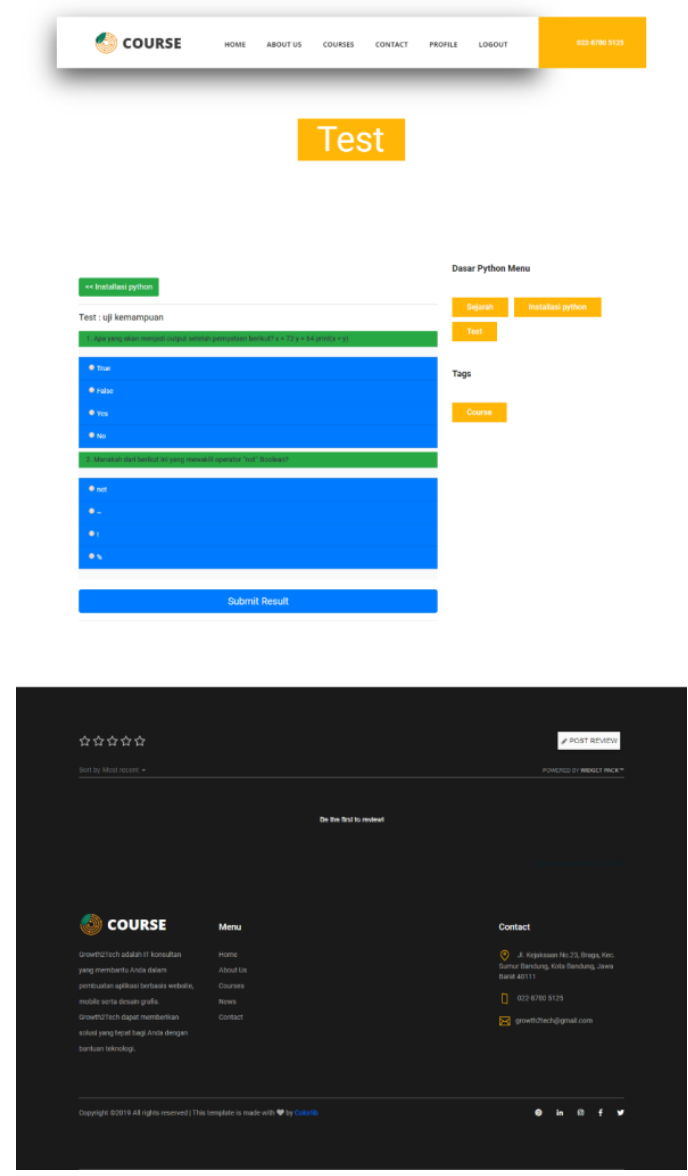

Gambar 39 Lesson page question

Gambar diatas adalah Lesson page question disini user melakukan test dan user bisa me review test tersebut

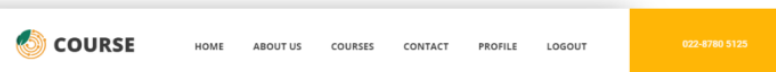

\section{Test}

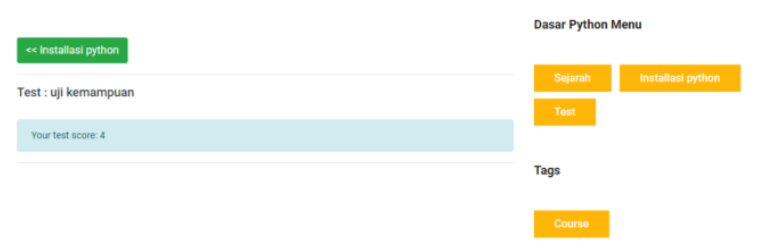

Gambar 40 Hasil test

Gambar diatas adalah Hasil test disini user dapat melihat nilai hasil test 


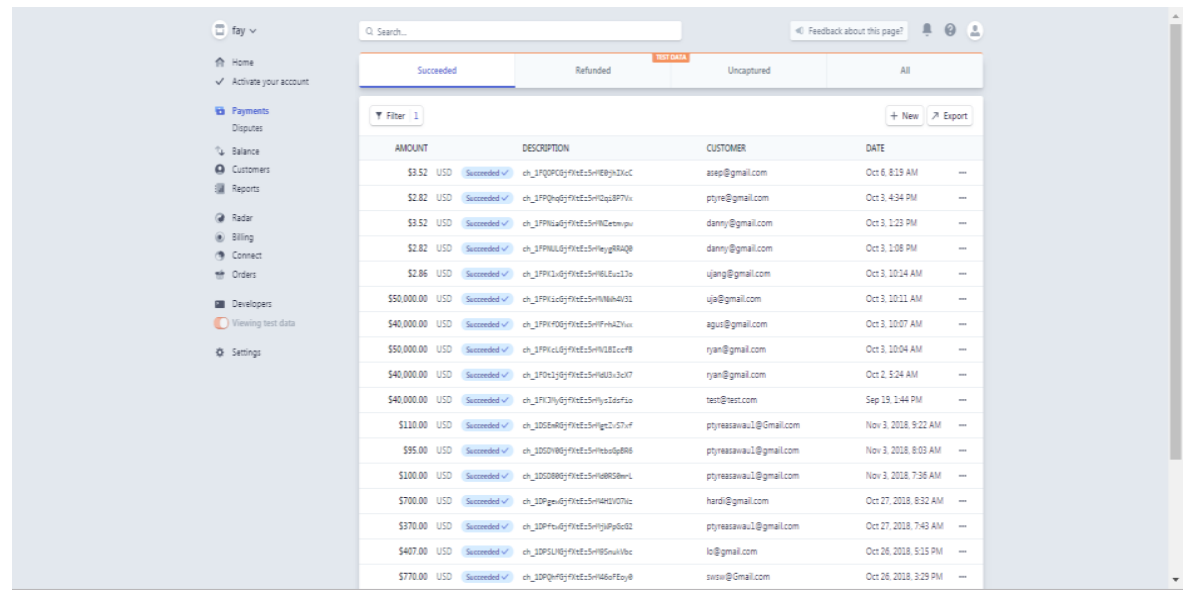

Gambar 41 Hasil payment

Sumber:

https://dashboard.stripe.com/test/payments?status\%5B\%5D=successful

Gambar diatas adalah Hasil pembelian course yang tercatat pada website stripe.com

\section{2) Rencana Pengujian}

Adapun rancangan pengujian sistem yang akan diuji dengan teknik pengujian Black Box akan dikelompokan pada tabel dibawah ini :

Tabel 16 Black Box

\begin{tabular}{cccc}
\hline No & Komponen yang sedang diuji & Butir uji & $\begin{array}{c}\text { Jenis } \\
\text { pengujian }\end{array}$ \\
\hline 1 & Roles menu di admin panel & (crud) data & Black box \\
\hline 2 & Users menu di admin panel & (crud) data & Blackbox \\
\hline 3 & Action menu di admin panel & $\begin{array}{c}\text { View data } \\
\text { merecord atau } \\
\text { tidak }\end{array}$ & Blackbox \\
\hline 4 & Courses menu di admin panel & Crud data & Blackbox \\
\hline 5 & Lesson menu di admin panel & Crud data & Blackbox \\
\hline 6 & Question menu di admin & Crud data & Blackbox \\
\hline 7 & Question_option menu di & Crud data & Blackbox \\
\hline 8 & Test menu di admin panel & Crud data & Blackbox \\
\hline 9 & Change password & Crud data & Blackbox \\
\hline 10 & Logout & Tombol logot & Blackbox \\
\hline 11 & Login & Tombol login & Blackbox \\
\hline
\end{tabular}

\section{Kasus dan Hasil Pengujian}

Berikut ini adalah kasus untuk menguji perangkat lunak yang sudah dibangun menggunakan metode Black Box berdasarkan Tabel Rencana pengujian yang dibuat sebelumnya. 
Tabel 17 Pengujian

\begin{tabular}{|c|c|c|c|c|}
\hline No & $\begin{array}{l}\text { Fungsi yang } \\
\text { diuji }\end{array}$ & Cara Pengujian & Hasil Yang diharapkan & $\begin{array}{c}\text { Hasil } \\
\text { Pengujian }\end{array}$ \\
\hline 1 & Roles & $\begin{array}{l}\text { add, edit, dan } \\
\text { delete data }\end{array}$ & $\begin{array}{l}\text { Semua data masuk dan } \\
\text { terhapus di database }\end{array}$ & Berhasil \\
\hline 2 & Users & $\begin{array}{l}\text { add, edit, dan } \\
\text { delete data }\end{array}$ & $\begin{array}{l}\text { Semua data masuk dan } \\
\text { terhapus di database dan } \\
\text { submenu berfungsi }\end{array}$ & Berhasil \\
\hline 3 & Action & Perubahan data & $\begin{array}{c}\text { Semua data yang berubah } \\
\text { di rekam disini }\end{array}$ & Berhasil \\
\hline 4 & Course & $\begin{array}{l}\text { add, edit, dan } \\
\text { delete data }\end{array}$ & $\begin{array}{l}\text { Semua data masuk dan } \\
\text { terhapus di database dan } \\
\text { submenu berfungsi }\end{array}$ & Berhasil \\
\hline 5 & Lesson & $\begin{array}{l}\text { add, edit, dan } \\
\text { delete data }\end{array}$ & $\begin{array}{c}\text { Semua data masuk dan } \\
\text { terhapus di database dan } \\
\text { submenu berfungsi }\end{array}$ & Berhasil \\
\hline 6 & Question menu & $\begin{array}{l}\text { add, edit, dan } \\
\text { delete data }\end{array}$ & $\begin{array}{c}\text { Semua data masuk dan } \\
\text { terhapus di database dan } \\
\text { submenu berfungsi }\end{array}$ & Berhasil \\
\hline 7 & Question_option & $\begin{array}{l}\text { add, edit, dan } \\
\text { delete data }\end{array}$ & $\begin{array}{l}\text { Semua data masuk dan } \\
\text { terhapus di database dan } \\
\text { submenu berfungsi dan } \\
\text { submenu berfungsi }\end{array}$ & Berhasil \\
\hline 7 & Question_option & $\begin{array}{l}\text { add, edit, dan } \\
\text { delete data }\end{array}$ & $\begin{array}{c}\text { Semua data masuk dan } \\
\text { terhapus di database dan } \\
\text { submenu berfungsi dan } \\
\text { submenu berfungsi }\end{array}$ & Berhasil \\
\hline 8 & Test & $\begin{array}{l}\text { add, edit, dan } \\
\text { delete data }\end{array}$ & $\begin{array}{l}\text { Semua data masuk dan } \\
\text { terhapus di database dan } \\
\text { submenu berfungsi }\end{array}$ & Berhasil \\
\hline 9 & $\begin{array}{l}\text { Change } \\
\text { password }\end{array}$ & Edit & $\begin{array}{c}\text { Data password user } \\
\text { berubah }\end{array}$ & Berhasil \\
\hline 10 & Login & Tombol login & $\begin{array}{l}\text { User masuk ke sistem } \\
\text { sesuai denga role nya }\end{array}$ & Berhasil \\
\hline
\end{tabular}

\section{Kesimpulan}

Dari hasi analisi dan perancangan Aplikasi Sistem Manajemen Belajar Berbasis WEB dengan Framework Laravel, maka dapat mengambil beberapa kesimpulan sebagai berikut :

1. Kegiatan pelatihan di Growth2tech tidak lagi konvensional dan menjadi online yang dapat mempermudah dalam hal pembelajaran dan pelatihan dan fleksibel dalam waktu unutk mengikuti pelatihan

2. Adanya sistem manajemen belajar mempermudah dalam memanajemen kegiatan pelatihan di Growth2tech yang membantu guru dalam menyiapkan soal atau materi 


\section{BIBLIOGRAFI}

Ariata, Apa Itu NGINX? Dan Bagaimana Cara Kerjanya? [online], Avaliable : https://www.hostinger.co.id/tutorial/apa-itu-nginx/ [2019, Mei 26]

Arumsari, Mutiara, Microsoft Visual Studio Code: Seperti Apa Fiturnya? [online], Avaliable : https://blog.dicoding.com/microsoft-visual-studio-code/ [2019, April 2].

Anggraeni dan Irviani, (2017), Pengantar Sistem Informasi ,penerbit CV. ANDI OFFSET, Yogyakarta.

Arumsari , Mutiara, Visual Studio Code, Editor Baru dari Microsoft Untuk Windows, OS $X$, dan Linux [online], Avaliable https://blog.dicoding.com/microsoftvisual-studio-code/ [.

Bitar, Sistem Informasi Manajemen - Pengertian , Fungsi, Tujuan, Proses, Kemampuan, Contohnya, [online], Avaliable : https://www.gurupendidikan.co.id/sistem-informasi-manajemen/ [2019, juni 16].

Fujimaru, Takagi, Laragon, Alternatif XAMPP Terbaik di Windows [online], Avaliable : https://www.codepolitan.com/laragon-alternatif-xampp-terbaik-di-windows5ae1bfaeb07be [2018, April 26].

Hamidin,Dini (2018), Analisis dan Perancangan Sistem Informasi Pembahasan Secara Praktis dengan contoh kasus, penerbit CV. BUDI UTAMA, Yogyakarta.

Jakaria, Ibnu Apa itu Composer? Dan Kenapa Harus Composer? [online], Avaliable : https://www.codepolitan.com/apa-composer-dan-kenapa-harus-composer [2019, January 21].

Nikko, Sora, Pengertian UML Dan Jenis-Jenisnya Serta Contoh Diagramnya [online], Avaliable : http://www.pengertianku.net/2015/09/pengertian-uml-dan-jenisjenisnya-serta-contoh-diagramnya.html [2015, september 24].

Nugraha, Apa itu browser?? pengertian, fungsi, contoh dan ulasan lengkap !! [online], Avaliable : https://nyengnyeng.com/apa-itu-browser/[2018, Febuari 5].

Munawar, (2018), Analisis Perancangan Sistem Berorientasi Objek dengan UML , penerbit gramedia Bandung

Saputra, Agus, (2017), Panduan Praktis dan Jitu Menguasai PHP7 dan SQL Server 2017, penerbit CV. ASFA Solution, Cirebon.

Setiawan, Didik, (2018), Buku Sakti Pemograman WEB: HTML, CSS, PHP, MySQL \& Javascript, penerbit START UP, Yogyakarta. 
Ponsen Sindu Prawito dan Hardiansyah Putera Perdana

Wahyuningsih, Dian, (2017), E-Learning Teori dan Aplikasi,penerbit informatika bandung, Bandung.

Wardana, Wayan, langkah-langkah penggunaan uml, [online], Avaliable : http://matematikakuadrat.blogspot.com/2009/06/langkah-langkahpenggunaan-uml.html [2019, juni 7].

Wicaksono, Soetam, (2017), Rekayasa Perangkat Lunak, penerbit Seribu Bintang, Malang.

Yudhanto, Yudho, (2019), Mudah Menguasai Framework Laravel, penerbit PT Elex Media Komputindo, Jakarta. 